U.S. Department of the Interior

U.S. Geological Survey

Prepared in cooperation with the Oregon Department of Transportation

\title{
Herbicide Use in the Management of Roadside Vegetation, Western Oregon, 1999-2000: Effects on the W ater Quality of Nearby Streams
}

W ater-Resources Investigations Report 01- 4065

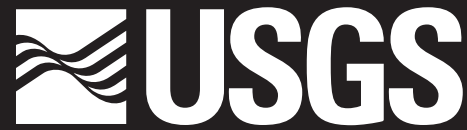




\section{Cover photograph:}

View looking east at the simulated rainfall experimental plots constructed on the road shoulder of Highw ay 211 at the crossing of Bull Creek near Colton, Oregon. 


\section{Herbicide Use in the Management of Roadside Vegetation, Western Oregon, 1999-2000: Effects on the W ater Quality of Nearby Streams}

By TAM ARA M. WOOD

W ater-Resources Investigations Report 01- 4065

Prepared in cooperation with the Oregon Department of Transportation

Portland, Oregon: 2001 


\section{U. S. DEPARTM ENT OF THE INTERIOR}

Gale A. Norton, Secretary

U.S. GEOLOGICAL SURVEY

CHARLES G. GROAT, Director

Any use of trade, product, or firm names in this publication

is for descriptive purposes only and does not imply

endorsement by the U.S. Government.

For additional information contact:

District Chief

U.S. Geological Survey

10615 S.E. Cherry B lossom Drive

Portland, OR 97216-3159

E-mail: info-or@usgs.gov

Internet: http://oregon.usgs.gov
Copies of this report can be purchased from:

USGS Information Services B ox 25286, Federal Center

Denver, CO 80225-0046

Telephone: 1-888-ASK-USGS

\section{Suggested citation:}

Wood, T.M., 2001, Herbicide use in the management of roadside vegetation, w estern Oregon, 1999- 2000Effects on the water quality of nearby streams: U.S. Geological Survey W ater-Resources Investigations Report 01- 4065, $27 \mathrm{p}$. 


\section{CONTENTS}

Summary

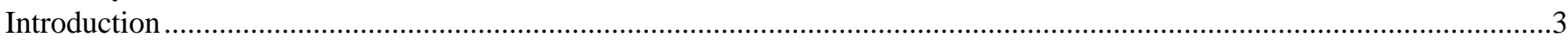

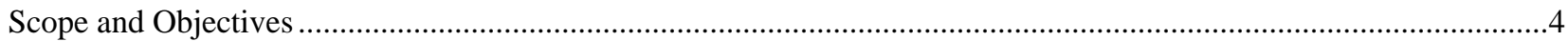

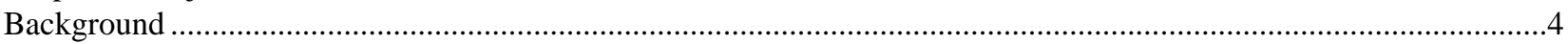

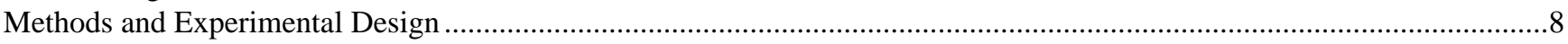

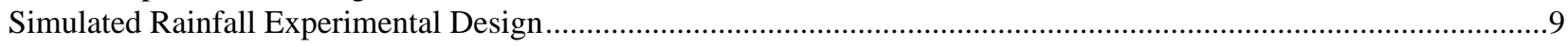

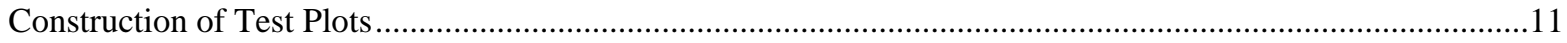

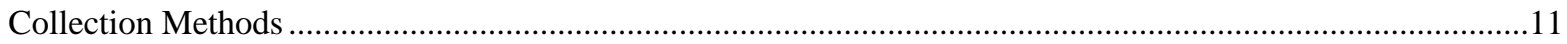

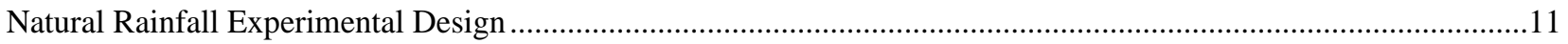

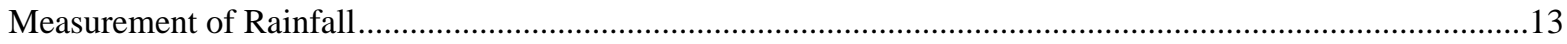

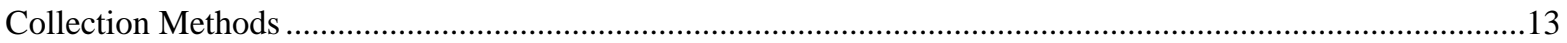

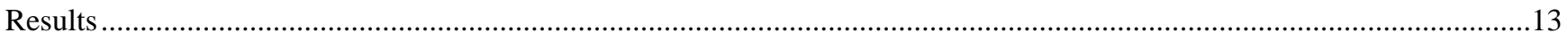

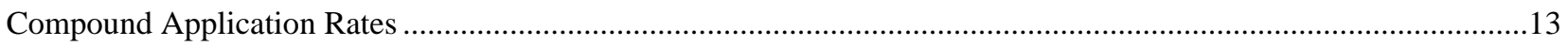

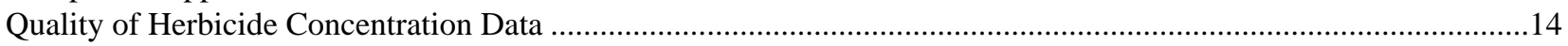

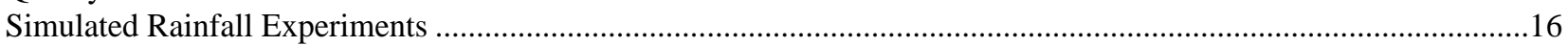

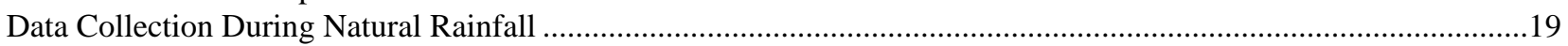

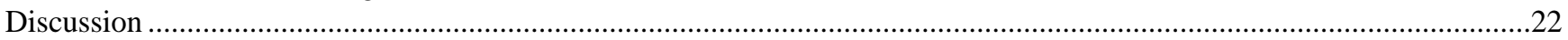

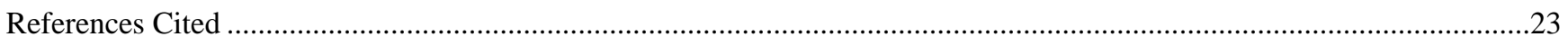

Appendix A: Summary of the liquid chromatography mass spectroscopy method for determining diuron,

bromacil, and sulfometuron-methyl concentration ..................................................................................................27

Appendix B: Summary of the method for determining deposition of diuron, bromacil, sulfometuron-methyl,

and glyphosate on absorbent deposition sheets by the Oregon Department of Agriculture .........................................27

FIGURES

1. Graph showing concentration of diuron in runoff samples collected from test plots at three sites

in Glenn County, California .......................................................................................................................

2. Site map of the intersection of Bull Creek and Highway 211 near Colton, Oregon.................................................

3. Schematic diagram of the triplicate simulated rainfall plots...............................................................................

4. Graph showing herbicide concentrations in runoff from test plots on the road shoulder near the intersection

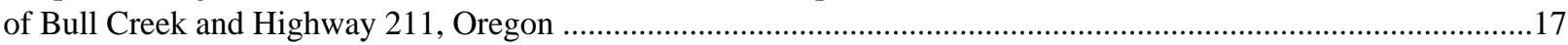

5. Graph showing rainfall data from Camp Adams rain gage ...............................................................................19

6. Graph showing diuron, sulfometuron-methyl, and bromacil concentrations in drainage ditches, runoff from the road shoulder, and Bull Creek measured during five rain events from October 1999 to January 2000 ..............21

TABLES

1. Observations of herbicide removal in simulated rainfall runoff from agricultural test plots......................................6

2. Percent removal of diuron and the percent of water applied that was collected as runoff from three test plots

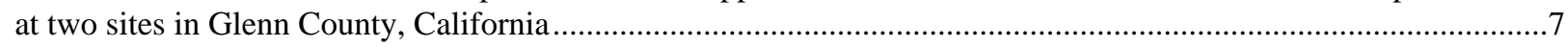

3. Summary of data collection during natural rainfall, October 1999 through January 2000.......................................12

4. Quality assurance data from the Oregon Department of Agriculture Laboratory for the method used to

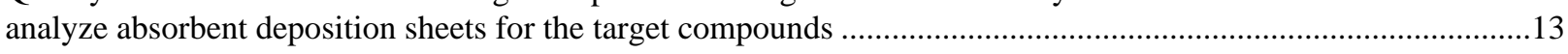

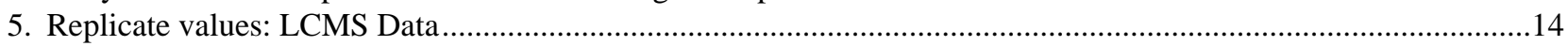

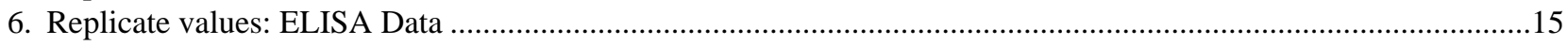

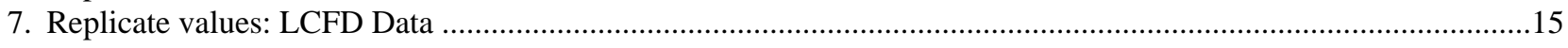

8. Spike Recoveries of LCMS data .........................................................................................................

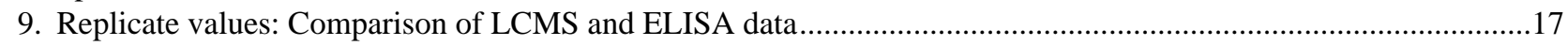

10. Fraction of water lost to infiltration during simulated rainfall experiments ...........................................................18

11. Concentration of fine-grained sediment in the runoff collected from the test plots ...............................................19

12. Accumulated rainfall and discharge in the stream and drainage ditches on each of the fall sampling dates .............20

13. Theoretical concentrations of herbicides in Bull Creek resulting from a hard rainfall between the first day and 2 weeks after compound application to the road shoulder, with discharges in the creek and drainage ditch as measured November 1999 to January $2000 .$. 


\begin{tabular}{|c|c|c|}
\hline Multiply & By & To obtain \\
\hline \multicolumn{3}{|c|}{ Length } \\
\hline inch (in.) & 2.54 & centimeter $(\mathrm{cm})$ \\
\hline foot $(\mathrm{ft})$ & 0.305 & meter $(\mathrm{m})$ \\
\hline mile (mi) & 1.61 & kilometer $(\mathrm{km})$ \\
\hline \multicolumn{3}{|c|}{ Area } \\
\hline square mile $\left(\mathrm{mi}^{2}\right)$ & 259.0 & hectare (ha) \\
\hline hectare (ha) & 2.471 & acre \\
\hline hectare (ha) & 0.003861 & square mile $\left(\mathrm{mi}^{2}\right)$ \\
\hline \multicolumn{3}{|c|}{ Volume } \\
\hline micrograms per liter $(\mu \mathrm{g} / \mathrm{L})$ & 1 & parts per billion (ppb) \\
\hline milligrams per liter (mg/L) & 1 & parts per million (ppm) \\
\hline liter $(\mathrm{L})$ & 0.2642 & gallon (gal) \\
\hline \multicolumn{3}{|c|}{ Flow rate } \\
\hline cubic feet per second (ft3/s) & 0.02832 & cubic meter per second $\left(\mathrm{m}^{3} / \mathrm{s}\right)$ \\
\hline \multicolumn{3}{|c|}{ Mass } \\
\hline kilogram (kg) & 2.205 & pound avoirdupois (lb) \\
\hline \multicolumn{3}{|c|}{ Application rate } \\
\hline kilograms per hectare $(\mathrm{kg} / \mathrm{ha})$ & 0.89 & pounds per acre \\
\hline
\end{tabular}

Temperature in degrees Celsius $\left({ }^{\circ} \mathrm{C}\right)$ may be converted to degrees Fahrenheit $\left({ }^{\circ} \mathrm{F}\right)$ as follows: ${ }^{\circ} \mathrm{F}=1.8^{\circ} \mathrm{C}+32$ 


\section{Herbicide Use in the Management of Roadside Vegetation, Western Oregon, 1999- 2000: Effects on the Water Quality of Nearby Streams}

By Tamara M. Wood

\section{Summary}

Previous studies by the U.S. Geological Survey (USGS) have established that many different herbicides can be found in small Willamette Valley streams. Several of the compounds detected in those studies were known to be used by the Oregon Department of Transportation (ODOT) as part of its integrated vegetation management (IVM) plan to control roadside vegetation. The purpose of this study was to assess whether the use of herbicides in IVM programs could be a significant contributor to the load of herbicides carried by streams in Oregon.

Field work was carried out at a site in the Willamette Valley near Colton, Oregon, where ODOT applied the herbicides Krovar (active ingredients diuron and bromacil), Oust (active ingredient sulfometuron-methyl) and Roundup (active ingredient glyphosate) as part of its integrated vegetation management program at the site. This combination of herbicides had not been used previously at this site, but it had been used by ODOT at other sites. The combination was chosen for this study for several reasons: diuron and bromacil were two compounds that were detected in the previous studies, and they may have been contributed by rights-of-way applications; glyphosate has a strong affinity for the solid phase, whereas the other compounds are relatively hydrophilic (water-soluble); and sulfometuron-methyl, a sulfonyl urea herbicide, is normally applied at a much lower rate than other types of herbicides (in this case at approximately one-fifth the rate of diuron and bromacil).

The field work was designed in two phases to examine the transport of herbicides from the road shoulders under both controlled and natural rainfall conditions. In the first phase, which took place in the spring of 1999, small test plots were constructed on the road shoulder near an intersection with Bull Creek, a small receiving stream that is tributary to the Molalla River, which flows into the Willamette River. Rainfall was simulated on these experimental plots one day after compound application and again 1 week and 2 weeks after compound application. The targeted rain intensity for the simulations was 0.3 inches per hour, representing a heavy but not rare storm for the area. The simulated rainfall was applied long enough to collect between 13 and 15 liters of runoff (between 0.5 and 1.9 hours, depending on the plot and the sample date).

Runoff of the compounds within 24 hours of application was greatest for sulfometuronmethyl (3.3-7.1\%), and less for diuron and glyphosate $(1.7-2.7 \%$ and $0.9-2.1 \%$ for diuron and glyphosate, respectively; bromacil was not measured in this phase). The event-mean concentration in the runoff of each of the herbicides declined by about 1.5 orders of magnitude from the first day after application to the second week after application. Concentrations of diuron ranged from 372 to $613 \mu \mathrm{g} / \mathrm{L}$ (micrograms per liter or parts per billion) on the first day after application, and from 23 to $28 \mu \mathrm{g} / \mathrm{L} 2$ weeks after application. Concentrations of glyphosate 
were of a similar magnitude, ranging from 323 to $736 \mu \mathrm{g} / \mathrm{L}$ on the first day after application and from 16 to $41 \mu \mathrm{g} / \mathrm{L} 2$ weeks after application. Sulfometuron-methyl concentrations were the lowest of the three target compounds, consistent with its lower application rate, and ranged from 119 to $253 \mu \mathrm{g} / \mathrm{L}$ on the day after application, and from 10 to $15 \mu \mathrm{g} / \mathrm{L} 2$ weeks later. The results of the simulated rainfall experiments suggested that a heavy rainstorm occurring soon after herbicide application could generate concentrations in the runoff leaving the road shoulder of nearly 1 milligram per liter (parts per million) glyphosate and diuron, and concentrations on the order of a few hundred micrograms per liter of sulfometuronmethyl. The concentration in the direct runoff from the road shoulder provides an upper limit for the mixing of waters that converge in the roadside ditch from the entire drainage, but probably overestimates the concentration in the ditch itself.

After a repeat spraying of the road shoulder at the end of September, the second phase of data collection took place from the end of October 1999 through early January 2000, during natural rainfall, in order to measure the loadings of the target compounds to Bull Creek from the drainage ditch under realistic conditions.

The fall diuron data show that concentrations in the runoff directly from the road shoulder remained in the $1-10 \mu \mathrm{g} / \mathrm{L}$ range throughout the 3-month sampling period; during this same period the concentrations in the roadside ditch decreased from about $10 \mu \mathrm{g} / \mathrm{L}$ in October to about $0.1 \mu \mathrm{g} / \mathrm{L}$ in January, indicating that as the fall/winter rainy season proceeded, more dilution of the runoff from the shoulder was occurring. Only in October, however, when the stream discharge was still at late-summer low levels, was diuron detected in Bull Creek, at concentrations between 0.1 and $0.3 \mu \mathrm{g} / \mathrm{L}$. The source of this diuron was, most likely, an unidentified upstream source rather than ODOT operations, as the diuron was detected upstream of the drainage ditch. A mass balance calculation confirmed that the load to Bull Creek from the drainage ditch was too low to result in detectable concentrations in the stream during the entire October to January time period.
Sulfometuron-methyl was detected in the 0.1 to $1 \mu \mathrm{g} / \mathrm{L}$ range in the runoff from the road shoulder throughout the 3-month sampling period, and in the drainage ditch decreased from about $1 \mu \mathrm{g} / \mathrm{L}$ in October and November to about $0.3 \mu \mathrm{g} / \mathrm{L}$ in January. Sulfometuron-methyl was never detected in Bull Creek, and the mass balance calculations confirmed that, in general, the load of sulfometuron-methyl to Bull Creek from the drainage ditch would not have resulted in detectable concentrations in the stream. On one sample date in November the highest drainage ditch concentrations could theoretically have produced concentrations of about $0.06 \mu \mathrm{g} / \mathrm{L}$ in the stream, but the stream samples did not show detectable concentrations of sulfometuronmethyl.

Bromacil concentrations were similar to those of diuron. Glyphosate was never detected in any of the fall samples from the road shoulder, the drainage ditch, or the stream.

Theoretical calculations using herbicide concentrations from the simulated rainfall experiments and the stream and ditch discharges measured during fall and winter rainfall indicated that in Bull Creek, a relatively small stream in which the fall and winter discharge is likely to be between 10 and $20 \mathrm{ft}^{3} / \mathrm{s}$ (cubic feet per second) ODOT operations could, conceivably, result in herbicide concentrations on the order of $1 \mu \mathrm{g} / \mathrm{L}$. This would require, however, a heavy rainfall (on the order of 0.3 inches per hour for about a 1-hour period) quite soon after the application of the compounds, a situation that ODOT personnel try to avoid and that is not routine.

For comparison, diuron concentrations in a previous study of herbicides in small Willamette Valley streams (Anderson et al., 1997) had a median value of $0.26 \mu \mathrm{g} / \mathrm{L}$, a 90 th percentile value of $4.2 \mu \mathrm{g} / \mathrm{L}$, and a maximum of $29 \mu \mathrm{g} / \mathrm{L}$, based on 94 samples and 69 detections. Bromacil, a compound that was identified as potentially contributed by roadside and rights-of-way applications, had a median value of less than $0.035 \mu \mathrm{g} / \mathrm{L}$ (the method detection limit), a 90th percentile of $0.31 \mu \mathrm{g} / \mathrm{L}$, and a maximum value of $51 \mu \mathrm{g} / \mathrm{L}$, based on 94 samples and 14 detections. 
Results of the current study indicate that ODOT operations could, conceivably, account for concentrations close to the 90th percentile of both of these compounds. Concentrations approaching the 90th percentile values of diuron and bromacil cited above would result, however, only if a heavy rainfall occurred soon after compound application.

After more than 3 months and 20 inches of rain at this site, diuron and bromacil, the active ingredients in Krovar, and sulfometuron-methyl, the active ingredient in Oust, were still found in the sprayed drainage ditch at measurable, although low, concentrations (less than $1 \mu \mathrm{g} / \mathrm{L}$ ). This indicates that, while the initial decrease in the availability of the compound for transport and its concentration in the runoff from the road shoulder is rapid, within a month after application that decrease is much slower. Thus, there appears to be a long-term residual of these compounds for many months after their application to the road shoulder. Because the total area that ODOT sprays is a small fraction of any given drainage basin, however, the concentrations in all but the most undiluted roadside drainage ditches would likely be unmeasurable at current method reporting limits.

\section{INTRODUCTION}

The Oregon Department of Transportation (ODOT) uses an integrated vegetation management (IVM) plan to control roadside vegetation. IVM programs utilize a suite of practices, including application of herbicides. The extent to which these herbicides are transported from the point of application on the road shoulders to nearby streams is unknown, but if large amounts of these herbicides end up in streams, then the stream biota could be adversely affected and the stream ecosystem disrupted. Small streams that parallel or cross roadways are particularly susceptible because their dilution capacity is small.

Previous studies by the U.S. Geological Survey (USGS) study established that many different herbicides can be found in small Willamette Valley streams (Anderson et al., 1997; Rinella and Janet, 1998). Several of the compounds detected in those studies were known to be used by ODOT in IVM programs, but none could be attributed solely to that use because they were known to have other uses on urban or agri- cultural land. Diuron and bromacil, for example, were compounds that were detected in the Anderson et al. (1997) study (detected in $73 \%$ and $15 \%$ of the samples analyzed for diuron and bromacil, respectively) and were identified as potentially having contributions from rights-of-way applications. Diuron has cropland uses, but was strongly associated with both urban and agricultural land use, indicating that noncropland applications were an important contribution to the measured concentrations (median $0.26 \mu \mathrm{g} / \mathrm{L}$, 90th percentile $4.2 \mu \mathrm{g} / \mathrm{L}$, and maximum $29 \mu \mathrm{g} / \mathrm{L}$ ). Bromacil does not have cropland uses but, like diuron, was associated with both urban and agricultural land use (median concentration less than $0.035 \mu \mathrm{g} / \mathrm{L}$ [the method detection limit], 90th percentile $0.31 \mu \mathrm{g} / \mathrm{L}$, and maximum $51 \mu \mathrm{g} / \mathrm{L}$ ). Further study was required, therefore, to assess whether the use of herbicides in IVM programs could be a significant contributor to the concentration of herbicides measured in Oregon streams.

The USGS entered into a cooperative agreement with ODOT to assist the ODOT Technical Advisory Committee in evaluating the potential for impacts on water quality in nearby streams after IVM application of herbicides. This report presents the results of the work done by the USGS as part of that agreement. The first part of the study was a literature review, excerpts from which are presented in the Background section of this report. Much of the information reviewed was obtained from the agricultural literature, as most studies examining the runoff of herbicides have been done in that context. Relatively little work has been done studying the transport of herbicides from road shoulders, although the results from one study done in Glenn County, California (Powell et al., 1996), are relevant.

As a result of the literature review, it was concluded that not enough was known about the fate and transport of herbicides used to control roadside vegetation to make a reasonable assessment of ODOT's potential contribution to the loads of herbicides carried by small Oregon streams. In particular, many of the site- and compound-specific variables that determine the fate and transport of herbicides could be very different in the setting of a highway right-of-way than in an agricultural setting. To address remaining uncertainties, a field study was initiated that included the collection of water samples targeted at an improved understanding of the transport of herbicides from the road shoulder. 


\section{Scope and Objectives}

Compounds are potentially transported from roadside application areas by several mechanisms, but the scope of this study was limited to the transport of herbicides from the application area to nearby streams by precipitation-induced runoff. Other mechanisms were judged to be secondary in importance to precipitation runoff for the purposes of this study. For example, volatilization and drift losses of a compound can be significant, but because the transport to nearby streams via those two mechanisms is likely to be small, those mechanisms were not considered for investigation in this study.

It was not within the scope of this study to collect data that is representative of all of the possible environmental conditions around the State. The cost of such a program would be prohibitive and would not be justified unless it can be demonstrated with a field program with a more limited scope, like this study, that the herbicides used in IVM programs are likely to be transported in large quantities to nearby streams, and that harm to the stream biota is a likely result.

The criteria used in selecting a site were that it have a relatively straightforward drainage and receiving stream configuration in order to facilitate the experimental setup and that it satisfy access and safety requirements, which required a relatively wide shoulder and visibility to oncoming traffic from both directions. Within those constraints, an effort was made to choose a site typical of ODOT's secondary roads in the Willamette Valley, in terms of pavement width, shoulder slope, shoulder vegetation, and shoulder fill soils.

The combination of herbicides used in this study-Krovar, Oust, Roundup-is a combination that is used by ODOT in its IVM program, and all formulations were applied at a rate and over an area consistent with normal ODOT procedures. The targeted compounds included a uracil (bromacil), sulfonyl urea (sulfometuron-methyl), phenyl urea (diuron), and an isopropylamine salt (glyphosate). The active ingredients in Krovar (bromacil and diuron) were identified in the Anderson et al. (1997) study as potentially having contributions from right-of-way applications. Glyphosate, the active ingredient in Roundup, has a high affinity for the solid phase, in contrast to the other three compounds, which are relatively hydrophilic. Sulfometuron-methyl, the active ingredient in Oust, offered the opportunity to assess a compound that is applied at much lower rates than the other three.
Spring fieldwork targeted a worst-case scenario in the environment, in which a heavy natural rainfall occurs soon after the compound is applied. Simulated rainfall was used in the spring field experiments so that both the amount of incident rainfall and its timing after application of the compound could be controlled. The targeted rainfall intensity was heavy for the area, but not extreme-characteristic of a storm that would be expected to occur at least once every year. The period of investigation in the spring was limited to 2 weeks after compound application.

Fall fieldwork was conducted under natural rainfall conditions and targeted the more likely situation in which rainfall does not occur until several weeks after the compounds are applied. The fall fieldwork also extended the period of investigation to several months after compound application.

The objectives of this study, within the established scope, were as follows:

- Determine how much of the targeted compounds is removed from the application area by a known volume of runoff resulting from a controlled application of simulated rainfall, over a 2-week period after application.

- Determine the relation between the concentration of the target compounds in drainage ditches that capture the runoff from the application area and the concentration in the receiving stream.

- Measure the concentrations of the target compounds in drainage ditches that empty directly to a small stream over a period of several months after compound application.

- Collect runoff and stream samples that will be used by other investigators to conduct bioassays to determine the toxicity of runoff collected from the application area and receiving stream water to a colonized species of benthic algae and to rainbow trout (data not presented or discussed in this report).

\section{Background}

The problem of herbicide transport in surface runoff from agricultural applications has been a focus of investigation in the agricultural literature for decades (see reviews in Leonard, 1988; Leonard et al., 
1979; Wauchope, 1978; Bailey et al., 1974; Pionke and Chesters, 1973), but little detailed investigation of the transport of herbicides in surface runoff from roadside applications has been done. Virtually all of the basic theory of herbicide entrainment and transport in runoff has been developed in an agricultural context, but most of this information is directly applicable to the roadside application of herbicides. In particular, the most important factors that affect herbicide entrainment and transport in runoff in the first few days and weeks after application-rainfall timing, intensity, and duration, and total runoff volumeinfluence the transport of compounds used in IVM programs in a manner analogous to how they influence the transport of agricultural compounds.

The amount of compound removed by the first significant runoff event after application is nearly always greater than that removed by subsequent events. The decline with subsequent events in the total amount of the compound removed, as well as the runoff concentration, is often almost exponential with respect to time after application (Leonard, 1988; Edwards, et al., 1980; Rhode et al., 1979; Smith et al., 1978; White et al., 1976). Furthermore, the availability of a compound for transport usually declines with time even in the absence of precipitation. This decline in availability can be attributed to a decrease in the total amount of compound stored in the surface layer of the soil (degradation), or to a decrease in the readily mobilized fraction because of a slow, progressive adsorption onto the soil matrix or a progressive migration to more strongly binding adsorption sites. The longer the lag time between compound application and the first runoff event, therefore, the less of the compound that will be removed in that event (Leonard et al., 1979; Wauchope and Leonard, 1980). Consequently, the timing of the first significant runoff event with respect to compound application is important in determining how much of the compound applied to the soil surface will be removed by runoff (Gaynor et al., 1995; Hall et al., 1991; Lennartz et al., 1997; Ritter et al., 1974; Shipitalo et al., 1997). Because rainfall timing, intensity, and duration are so critical, early in the history of the investigation of these processes investigators developed a technique to do controlled experimentation by applying simulated rainfall to small test plots and collecting the runoff at the base of the plot for analysis.

Several studies in which simulated rainfall was used to control the timing and duration of precipitation on small test plots have demonstrated a rapid decline in the concentration and percent removal of a compound with subsequent events. A few of those studies from the last 10 years are summarized in table 1. More comprehensive reviews are given elsewhere (Larson et al., 1997; Leonard, 1988), but the examples given in table 1 are representative. Comparing the runoff concentration of compounds applied at different rates can be misleading, as the concentration is roughly proportional to the application rate, in addition to being influenced by physical and chemical factors. For example, chlorimuron, nicosulfuron (Afyuni et al., 1997), and sulfometuron-methyl (Wauchope et al., 1990) were applied at rates one or two orders of magnitude less than the rate at which other compounds were applied, and the runoff concentrations of those compounds were correspondingly less. The amount removed by surface runoff as a fraction of the amount applied, however, was greater than $1 \%$ on the first day after application in each case. The discussion of compound removal in terms of the percent of the compound applied (REM in table 1) rather than runoff concentration makes the comparison of compounds applied at different rates more straightforward. All of the studies shown in the table documented compound removal greater than $1 \%$ at 1 or 2 days postapplication, and most documented compound removal greater than $2 \%$, sometimes much greater.

The literature review yielded only one field study that was specifically designed to examine the transport of herbicides applied to roadsides for vegetation management (Powell et al., 1996). In that study, which was done in Glenn County, California, simulated rainfall was applied to small roadside test plots analogous to those used in agricultural runoff studies. Runoff from simulated rainfall was collected from two roadside shoulder sites at 2-week intervals after simazine and diuron were applied to the sites. Three test plots were constructed at each site. Simulated rain was applied to the first of three test plots at each site immediately after application of the compounds, and again 2 weeks later. Simulated rain was applied to the second test plot for the first time 2 weeks after application of the compounds, and again 2 weeks later. Simulated rain was applied to the third test plot for the first time 4 weeks after application of the compounds, and again 2 weeks later. Another site with two similarly constructed test plots was used to collect runoff from natural rainfall. 
Table 1. Observations of herbicide removal in simulated rainfall runoff from agricultural test plots

[Runoff concentration is in whole water, unless otherwise specified. REM, compound removal; CT, conventional tillage; NT, no tillage or mulched tillage; CP, chisel plowed; ST, contoured strip-till; SC, suspension concentrate; EC, emulsifiable concentrate; DG, dispersible granule; na, not available; (d), dissolved; (s), sediment-associated; kg AI/ha, kilograms active ingredient per hectare; $\mu \mathrm{g} / \mathrm{L}$, micrograms per liter; \%, percent; wk, week; cm, centimeters; mm, millimeters; hr, hour; in, inches; L, liters; <, less than; $\leq$, less than or equal to; >, greater than I

\begin{tabular}{|c|c|c|c|c|c|c|}
\hline Compound & $\begin{array}{c}\text { Time } \\
\text { since } \\
\text { application }\end{array}$ & $\begin{array}{c}\text { Application } \\
\text { rate } \\
\text { (kg Al/ha) }\end{array}$ & $\begin{array}{c}\text { Runoff } \\
\text { concentration } \\
\mu \mathrm{g} / \mathrm{L}\end{array}$ & $\begin{array}{l}\text { REM } \\
(\%)\end{array}$ & Comments & Reference \\
\hline atrazine & $\begin{array}{l}1 \text { day } \\
1 \mathrm{wk} \\
2 \mathrm{wk}\end{array}$ & na & $\begin{array}{l}850-970 \\
380-540 \\
280-500\end{array}$ & $\begin{array}{l}4.6-7.2 \\
1.6-4.5 \\
0.6-1.1\end{array}$ & $\begin{array}{l}\text { Average of event mean concentration over six simulations of } \\
2.68 \mathrm{~cm} \text { rain in } 10 \text { minutes }(6.3 \mathrm{in} / \mathrm{hr}) ; 89-98 \% \text { of metolachlor } \\
\text { and } 78-95 \% \text { of metribuzin in dissolved phase; } 1 \text { week and } 2\end{array}$ & $\begin{array}{l}\text { Bowman, et al., } \\
1994\end{array}$ \\
\hline metolachlor & $\begin{array}{l}<1 \text { day } \\
1 \mathrm{wk} \\
2 \mathrm{wk}\end{array}$ & na & $\begin{array}{l}820-1,070 \\
330-500 \\
270-430\end{array}$ & $\begin{array}{r}3.3-5.3 \\
1-2.4 \\
0.3-0.7\end{array}$ & $\begin{array}{l}\text { week removals for plots that received no prior simulated rainfall; } \\
\text { concentration and loss values were taken from figures and are } \\
\text { approximate. }\end{array}$ & \\
\hline $\begin{array}{l}\text { cyanazine SC } \\
\text { cyanazine DG } \\
\text { sulfometuron-methyl DG } \\
\text { sulfometuron-methyl EC }\end{array}$ & $\begin{array}{l}1 \text { day } \\
1 \text { day } \\
1 \text { day } \\
1 \text { day }\end{array}$ & $\begin{array}{r}4.5 \\
4.5 \\
.4 \\
.4\end{array}$ & $\begin{array}{c}4,000-8,000 \\
1,000-5,000 \\
100-500 \\
40-150\end{array}$ & $\begin{array}{l}1.4-3.4 \\
0.6-2.7 \\
0.7-2.3 \\
0.4-1.3\end{array}$ & $\begin{array}{l}\text { Event mean concentration range from } 12 \text { test plots; rain applied } \\
\text { at } 69 \mathrm{~mm} / \mathrm{hr}(2.7 \mathrm{in} / \mathrm{hr}) \text { until 5-6 L of runoff was collected; losses } \\
\text { increased in the order EC }<\mathrm{DG}<\mathrm{SC} \text {. }\end{array}$ & $\begin{array}{l}\text { Wauchope et al., } \\
1990\end{array}$ \\
\hline $\begin{array}{l}\text { alachlor } \\
\text { carbofuran } \\
\text { terbufos }\end{array}$ & $\begin{array}{l}\leq 2 \text { days } \\
\leq 2 \text { days } \\
\leq 2 \text { days }\end{array}$ & $\begin{array}{l}3.36 \\
1.12 \\
1.12\end{array}$ & $\begin{array}{l}130-730 \\
\text { not given } \\
\text { not given }\end{array}$ & $\begin{array}{l}<1-6 \\
1-11 \\
<1-7\end{array}$ & $\begin{array}{l}\text { Concentration in first } 3 \text { minutes of runoff; removal is total for } \\
63 \mathrm{~mm} \text { rainfall applied in } 1 \text { hour }(2.5 \mathrm{in} / \mathrm{hr}) \text {; losses from ST and } \\
\text { NT plots were less than from CT plots, but alachlor concentrations } \\
\text { in runoff from NT plots were high due to washoff of compound; } \\
\text { alachlor and carbofuran transported primarily in dissolved phase, } \\
\text { terbufos primarily on sediment. }\end{array}$ & $\begin{array}{l}\text { Felsot et al., } \\
1990\end{array}$ \\
\hline chlorimuron & $\begin{array}{l}1 \text { day } \\
1 \mathrm{wk}\end{array}$ & .014 & $\begin{array}{r}10-36 \\
2-10\end{array}$ & $\begin{array}{l}1.3-2 \\
<0.2\end{array}$ & $\begin{array}{l}\text { Concentration at } 5 \text { and } 20 \text { minutes into simulation; } 2.54 \mathrm{~cm} \text { rainfall } \\
\text { applied in } 30 \text { minutes }(2 \mathrm{in} / \mathrm{hr}) \text {; removal over first } 5 \text { minutes of sim- }\end{array}$ & $\begin{array}{l}\text { Afyuni et al., } \\
1997\end{array}$ \\
\hline nicosulfuron & $\begin{array}{l}1 \text { day } \\
1 \mathrm{wk}\end{array}$ & .014 & $\begin{array}{l}8-32 \\
2-19\end{array}$ & $\begin{array}{l}1.1-1.3 \\
<0.2\end{array}$ & $\begin{array}{l}\text { ulation; removal higher from NT than CT plots, possibly due to } \\
\text { washoff; transport primarily in dissolved phase; removals at } 1 \text { day } \\
\text { and } 1 \text { week from the same treatment plots. }\end{array}$ & \\
\hline atrazine & $\begin{array}{l}1 \text { day } \\
7 \text { days } \\
30 \text { days }\end{array}$ & 1.7 & $\begin{array}{c}109-145(\mathrm{~d}) \\
1,100-1,270(\mathrm{~s}) \\
92(\mathrm{~d}) ; 1,050(\mathrm{~s}) \\
20(\mathrm{~d}) ; 600(\mathrm{~s})\end{array}$ & $\begin{array}{r}1-1.8 \\
0.05-1.1 \\
0.06-.51\end{array}$ & $\begin{array}{l}\text { Concentration at } 10 \text { minutes into simulation; simulated rainfall } \\
\text { applied at } 64 \mathrm{~mm} / \mathrm{hr}(2.5 \mathrm{in} / \mathrm{hr}) \text { for } 50 \text { minutes; removal was reduced } \\
\text { by using post-emergence rather than pre-emergence application } \\
\text { because runoff and sediment removal was reduced by plant cover. }\end{array}$ & $\begin{array}{l}\text { Pantone et al., } \\
1992\end{array}$ \\
\hline isoproturon & $\begin{array}{l}2 \text { hr } \\
1 \text { day } \\
3 \text { days } \\
7 \text { days }\end{array}$ & 1.16 & $\sim 10-1,000$ & $\begin{array}{l}2.8-13.3 \\
1.8-17.2 \\
1.3-13.3 \\
1.5-11.2\end{array}$ & $\begin{array}{l}\text { Concentrations at the initiation of runoff; removal after rainfall } \\
\text { simulation at } 70 \mathrm{~mm} / \mathrm{hr}(2.8 \mathrm{in} / \mathrm{hr} \text { ) for } 1.5 \mathrm{hr} \text {; dichlorprop and } \\
\text { isoproturon transported primarily ( }>70 \%) \text { in the dissolved phase, } \\
\text { bifenox almost entirely in sediment phase; variation over different }\end{array}$ & $\begin{array}{l}\text { Klöppel, et al., } \\
1994\end{array}$ \\
\hline dichlorprop & $\begin{array}{l}2 \text { hr } \\
1 \text { day } \\
3 \text { days } \\
7 \text { days }\end{array}$ & 1.2 & $\sim 1-1,000$ & $\begin{array}{l}0.9-10.4 \\
0.9-16.7 \\
0.7-10.4 \\
0.7-8.3\end{array}$ & $\begin{array}{l}\text { soil types, crops, and slopes; } 1 \text { day and subsequent removal for plots } \\
\text { that received no prior simulated rainfall; losses were less from plots } \\
\text { with vegetative cover because runoff and sediment removal was } \\
\text { reduced; losses from the site with the greatest slope were much }\end{array}$ & \\
\hline bifenox & $\begin{array}{l}2 \mathrm{hr} \\
1 \text { day } \\
3 \text { days } \\
7 \text { days }\end{array}$ & .58 & not given & $\begin{array}{r}11.2-19 \\
7.8-21.6 \\
4.3-17.2 \\
3.4-13.8\end{array}$ & ger than from other sites. & \\
\hline
\end{tabular}


The results suggested that the concepts developed and quantified in agricultural research apply to transport in roadside runoff. The study showed that subsequent rainfall events removed less diuron (table 2) and that the concentration of diuron in surface runoff decreased over time (fig. 1). This was the case particularly at site 3: comparing the data collected from plots 1,2, and 3 at 0,2 , and 4 weeks, after application, respectively, with data from the same test plot 2 weeks later shows a greater decline in both removal and concentration than comparing the same data at 0,2 , and 4 weeks with data from the next test plot 2 weeks later. This comparison demonstrates the importance of antecedent precipitation, in addition to the 2-week interval, in producing the decline in removal and concentration. At site 2 there appear to be plot-specific differences that confound the results; in particular it is difficult to interpret the lower concentration at plot 2, 2 weeks after application as a decrease with time because the concentration at plot 1 , which received antecedent precipitation, was higher. Some general statements about the differences between the two sites can be made, however. Overall, site 2 was characterized by more infiltration than site 3 (table 2), generally less compound removal, and generally lower concentrations in the runoff (fig. 1). Other factors being equal, more infiltration and less total volume of runoff will result in a lower compound removal by surface runoff, thus the lower percentages of removal at site 2 compared to site 3 are consistent with the lower runoff at that site. Assuming that greater infiltration carries more of the compound

Table 2. Percent removal of diuron and the percent of water applied that was collected as runoff (in parentheses) from three test plots at two sites in Glenn County, California [Powell et al., 1996]

\begin{tabular}{|c|c|c|c|c|c|}
\hline & \multicolumn{4}{|c|}{ Weeks after application } \\
\hline & & 0 & 2 & 4 & 6 \\
\hline \multirow{3}{*}{$\begin{array}{l}N \\
\stackrel{\infty}{\omega}\end{array}$} & plot 1 & $\begin{array}{c}3.2 \\
(10.5)\end{array}$ & $\begin{array}{c}1.9 \\
(11.6)\end{array}$ & & \\
\hline & plot 2 & & $\begin{array}{c}.5 \\
(9.6)\end{array}$ & $\begin{array}{c}0.3 \\
(5.1)\end{array}$ & \\
\hline & plot 3 & & & $\begin{array}{c}.2 \\
(4.8)\end{array}$ & $\begin{array}{c}0.4 \\
(10.5)\end{array}$ \\
\hline \multirow{3}{*}{$\begin{array}{l}m \\
\stackrel{D}{\omega} \\
\frac{1}{\omega}\end{array}$} & plot 1 & $\begin{array}{c}5.4 \\
(16.7)\end{array}$ & $\begin{array}{c}3.3 \\
(29.4)\end{array}$ & & \\
\hline & plot 2 & & $\begin{array}{r}4.7 \\
(23.3)\end{array}$ & $\begin{array}{r}2.9 \\
(46.2)\end{array}$ & \\
\hline & plot 3 & & & $\begin{array}{c}4.7 \\
(33.1)\end{array}$ & $\begin{array}{c}2.5 \\
(33.3)\end{array}$ \\
\hline
\end{tabular}

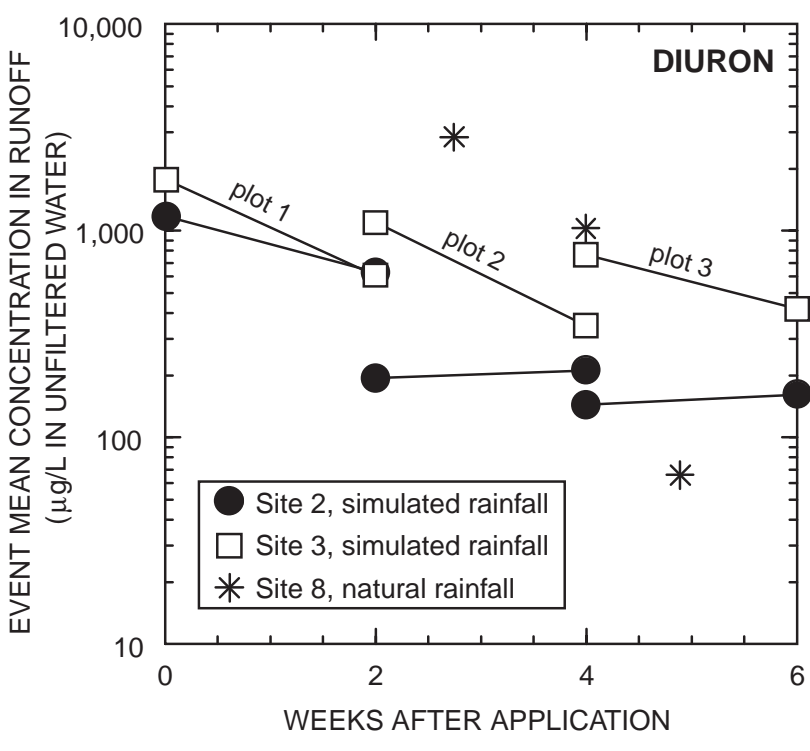

Figure 1. Concentration of diuron in runoff samples collected from test plots at three sites in Glenn County, California, as reported in tables from Powell et al. (1996).

beneath the top few centimeters of soil, the lower concentrations at site 2 are also consistent with the greater infiltration at that site. The comparison between sites 2 and 3 in the Glenn County study suggests that downward trends in removal and concentration with time are most obvious when more of the compound remains at the soil surface longer.

The diuron concentration in the runoff collected from site 8 during natural rainfall at 2.5 and 4 weeks after application (fig. 1) is higher than or comparable to the diuron concentration in runoff from the simulated rainfall events at sites 2 and 3. (Over $100 \mathrm{~mm}$ of rain fell at site 8 between the collection of samples at 4 and 4.6 weeks after application, so the lower concentration at 4.6 weeks probably indicates that removal of the compound occurred during that interval, but was not sampled.) Based on the comparison between the results from natural rainfall and simulated rainfall, it does not appear that the simulated rainfall conditions were unrealistic, and the use of small test plots seems to be a valid means of performing controlled experiments, rather than being subject to the vagaries of natural weather patterns.

It is difficult to make quantitative comparisons between the Glenn County study and agricultural studies such as those reported in table 1 because of differences in the intensity and duration of the rainfall applied, differences in the compounds applied and the application rate, and differences in how the runoff was collected (instantaneous or composited). It is useful to 
observe, however, that road shoulders are highly compacted environments with generally very little vegetation and a low organic carbon content. Indeed, road shoulders are engineered to promote runoff, whereas in an agricultural situation the goal is usually to promote infiltration to the extent possible. This suggests that the removal of herbicides from roadsides could be higher than what has been found for small fields and agricultural test plots, either because road shoulders are likely to be highly compacted, thus promoting less infiltration and more runoff, or because herbicides with some degree of hydrophobicity have a higher affinity for agricultural soils because of their greater organic carbon content.

\section{METHODS AND EXPERIMENTAL DESIGN}

The situation most likely to result in stream concentrations high enough to be detrimental to aquatic biota is that in which a roadside area that has been treated with herbicides as part of an IVM program drains to a small receiving stream. This situation is most likely to occur where a small stream flows beneath a road at a culvert or a small bridge, or parallels the road for some distance. This was the type of situation targeted for the field phase of this study.

In the spring, small test plots were constructed on the road shoulder near an intersection with a small receiving stream. Rainfall was simulated on these test plots 1 day after compound application and again 1 week and 2 weeks after compound application. The surface runoff from each plot was diverted to a small opening at the base of the plot and collected into a large stainless steel container. The event-composited runoff was passed on to the investigators responsible for the toxicological experiments. Small volumes were removed periodically from the runoff stream for analysis of the concentration of the targeted compounds.

The concentration of the target herbicides applied to the road shoulder in the runoff collected directly from the base of the test plots would be expected to overestimate the concentration in runoff actually reaching a nearby stream. In a realistic roadside application situation, herbicides are applied only to a fraction of the whole drainage basin. The concentration in the runoff actually reaching the stream, therefore, is diluted by water from the extra drainage area, and the concentration over a rainfall event is influenced by travel time from the most remote parts of the drainage basin. The impact on the stream is determined by the total amount of herbicide delivered during natural rainfall events. Therefore, in addition to the runoff collected during the simulated rainfall experiments in the spring, runoff from the drainage ditches and water from the receiving stream was collected during several natural rainfall events in the fall after a second application of herbicides in order to determine the load of herbicide delivered to the stream under realistic conditions.

Site Description.- The site was located at the intersection of Bull Creek with Highway 211, approximately 2 mi (miles) west of Colton, Oregon (fig. 2).

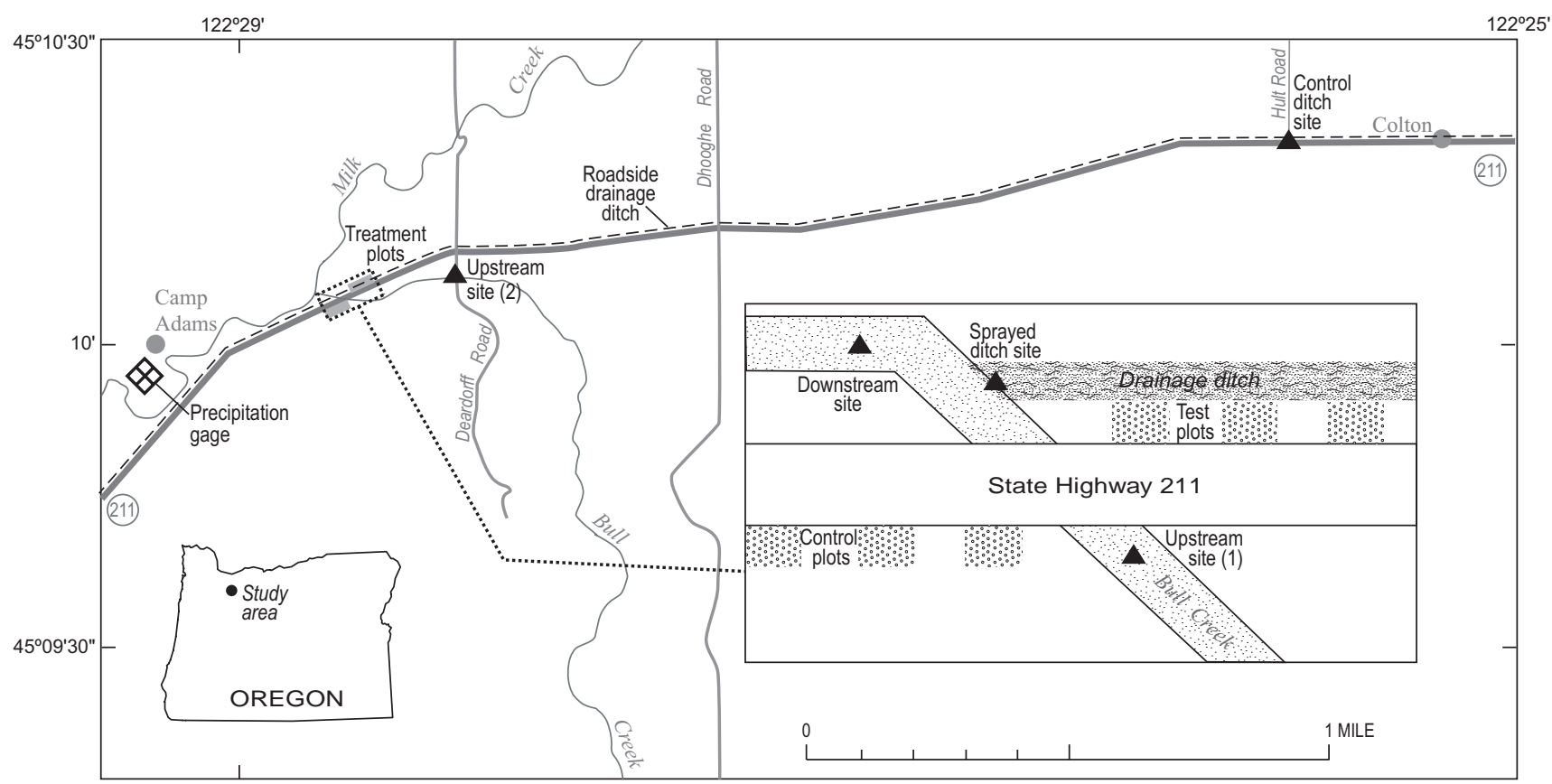

Figure 2. The intersection of Bull Creek and Highway 211 near Colton, Oregon. 
This site was chosen based on the configuration of the road, receiving stream, and drainage ditches, the safety and feasibility of working on the road shoulder, and the land use of the drainage basin. At this site, Bull Creek passes under Highway 211 through a cement box culvert.

The shoulders of the road are heavily compacted and composed of road construction fill material imported to the site. On the north side of the road where the test plots were constructed, the shoulder extends about $7 \mathrm{ft}$ (feet) from the pavement, the inner $5 \mathrm{ft}$ is almost entirely sand and gravel, and the outer $2 \mathrm{ft}$ is primarily sand and gravel mixed with some soil. The outer $2 \mathrm{ft}$ of the test plots contained some vegetation. At approximately $7 \mathrm{ft}$ from the pavement, the shoulder slopes sharply into a well-defined drainage ditch that drains the roadway to the east of the intersection. The drainage ditch is cut into local soils and is vegetated. The soil type of the surrounding area is a deep, well-drained silt loam (Gerig, 1985).

Bull Creek is a small stream with a drainage area of approximately 5 square miles. The discharge of the stream, based on measurements made as part of the fall sample collection effort, varies from about $1 \mathrm{ft}^{3} / \mathrm{s}$ (cubic feet per second) in the late summer to about $20 \mathrm{ft}^{3} / \mathrm{s}$ in midwinter. The land use in the basin is primarily rural-residential; it was judged during site reconnaissance that contributions of herbicides from intensively agricultural land use would not be a confounding factor. The nonagricultural use of herbicides by individual property owners could not, however, be ruled out because there is development in the drainage basin.

Application of Target Compounds.-ODOT applied a combination of the formulations Krovar, Oust, and Roundup to the site on May 19, 1999, during its routine spring applications. The active ingredients in these formulations are bromacil, diuron, sulfometuron-methyl, and glyphosate. The compounds were applied to the same shoulder area (a 4-ft swath starting from the edge of the pavement) and at the same rates that are normally used by ODOT. The targeted application rates were $1.34 \mathrm{~kg} / \mathrm{ha}$ (kilograms per hectare, or 1.19 pounds per acre) of diuron and bromacil, $0.26 \mathrm{~kg} / \mathrm{ha}$ ( 0.23 pounds per acre) of sulfometuron-methyl, and $2.24 \mathrm{~kg} / \mathrm{ha}$ (1.99 pounds per acre) of glyphosate. Herbicides were applied to the shoulder on both sides of the road east of the stream crossing; the sprayed plots were located east of the stream crossing on the north side of the road. Road shoulders west of the stream crossing were not sprayed; the control plots were located west of the stream crossing on the south side of the road (fig. 2).

An independent measurement of compound application was made using plastic-backed absorbent sheets placed on the ground before the spray truck passed through the area. These sheets measured 10 by 12 inches and were staked into the road shoulder. After application, the sheets were placed in glass jars, chilled, and sent to a laboratory at the Oregon Department of Agriculture for analysis of the target compounds by high-performance liquid chromatography (HPLC; appendix B).

\section{Simulated Rainfall Experimental Design}

Rainfall was simulated with commercially available sprinkler heads designed for landscape use (manufactured by Hunter Industries Inc.). Commercial sprinklers tend to produce smaller droplets with less kinetic energy than natural rainfall, especially at low intensities, potentially resulting in less mixing between surface water and interstitial water at the soil surface. This effect is less important at the small slopes and low infiltration rates that characterize the test plots in this study (Ahuja, 1986; Ahuja et al., 1982). In addition, because the road shoulder contains so much gravel, much of the kinetic energy of the drops is dissipated by impact with the surface roughness before mixing occurs. Water was supplied from an ODOT tank truck filled with Bull Creek water. The truck had not previously been used for herbicides, and was flushed before the rain simulation experiments. The water from the truck was passed through a manifold with a pressure sensor and then to three hoses so that triplicate plots were rained on simultaneously (fig. 3). The sprinklers were calibrated prior to the simulation experiments, and additional checks were made at the site. In order to provide uniform coverage over the test plots, the sprinklers rotated continuously through 180 degrees. As a result, no part of the test plot received rainfall $100 \%$ of the time, and the instantaneous rainfall intensity on any part of the test plot would be somewhat higher than the target intensity, which was measured as an average over 8 minutes during the calibration process. Natural rainfall also is characterized by short bursts of higher intensity, but the averaged value is intercomparable with rain gage data, which is averaged over the sampling interval (usually an hour). 
The choice of rain intensity for the simulated rainfall experiments was a trade-off between using an intensity strong enough to generate surface runoff for collection and the desire to mimic a storm that was more normal than extreme. The targeted rain intensity selected for the simulations was $0.3 \mathrm{in} / \mathrm{hr}$ (inches per hour). This intensity generated the required amount of runoff from each test plot in a reasonable time frame and represented a heavy storm for the area, but not an extremely rare storm. An intensity-duration-frequency analysis by the Oregon Department of Transportation (1990) shows this site to be at the boundary of two zones, where a 1-hour rainfall intensity with a return frequency of 2 years was calculated to be 0.54 and $0.45 \mathrm{in} / \mathrm{hr}$, respectively. Rainfall intensities with lower return frequencies were not calculated, but a $0.3 \mathrm{in} / \mathrm{hr}$, 1 -hour storm would clearly have a return frequency of less than 2 years.

Simulated rain was applied to three sprayed plots and three control plots 1 day after compound application (May 20, 1999), and again at 1 and 2 weeks after application (May 26 and June 3, 1999, respectively). The procedure for sample collection from the sprayed plots and the control plots was identical. On each date, the runoff collected over the length of the rainfall event from each sprayed plot and each control plot and was delivered to investigators at Portland State University for use in the fish and algal bioassays.
The composited runoff from each test plot was subsampled for a smaller volume to determine suspended sediment and glyphosate concentration. Glyphosate concentration in unfiltered water was determined using liquid chromatography and fluorescence detection (LCFD, Winfield et al., 1990) at the USGS National Water Quality Laboratory (NWQL) in Denver, Colorado. Suspended sediment concentration, measured because glyphosate was expected to be transported primarily in the sediment phase, was determined at the USGS Cascades Volcano Observatory (CVO) Laboratory in Vancouver, Washington.

The concentrations of the herbicides diuron and sulfometuron-methyl in the filtered runoff were determined using enzyme-linked immunosorbent assay (ELISA) methods. Commercially available kits from Strategic Diagnostics, Inc., were used. These kits measure total urea herbicide and sulfonyl urea herbicide, respectively; conversion factors supplied by the manufacturer were used to convert the standards supplied by the manufacturer to the target compounds. The resulting concentration data are, however, only semiquantitative. Because ELISA techniques require small sample volumes and the collection procedure used in the field was fast and simple, it was possible to collect samples to measure instantaneous concentration in the runoff at relatively short time intervals (about 5-20 minutes) over the course of the rainfall simulation experiment.

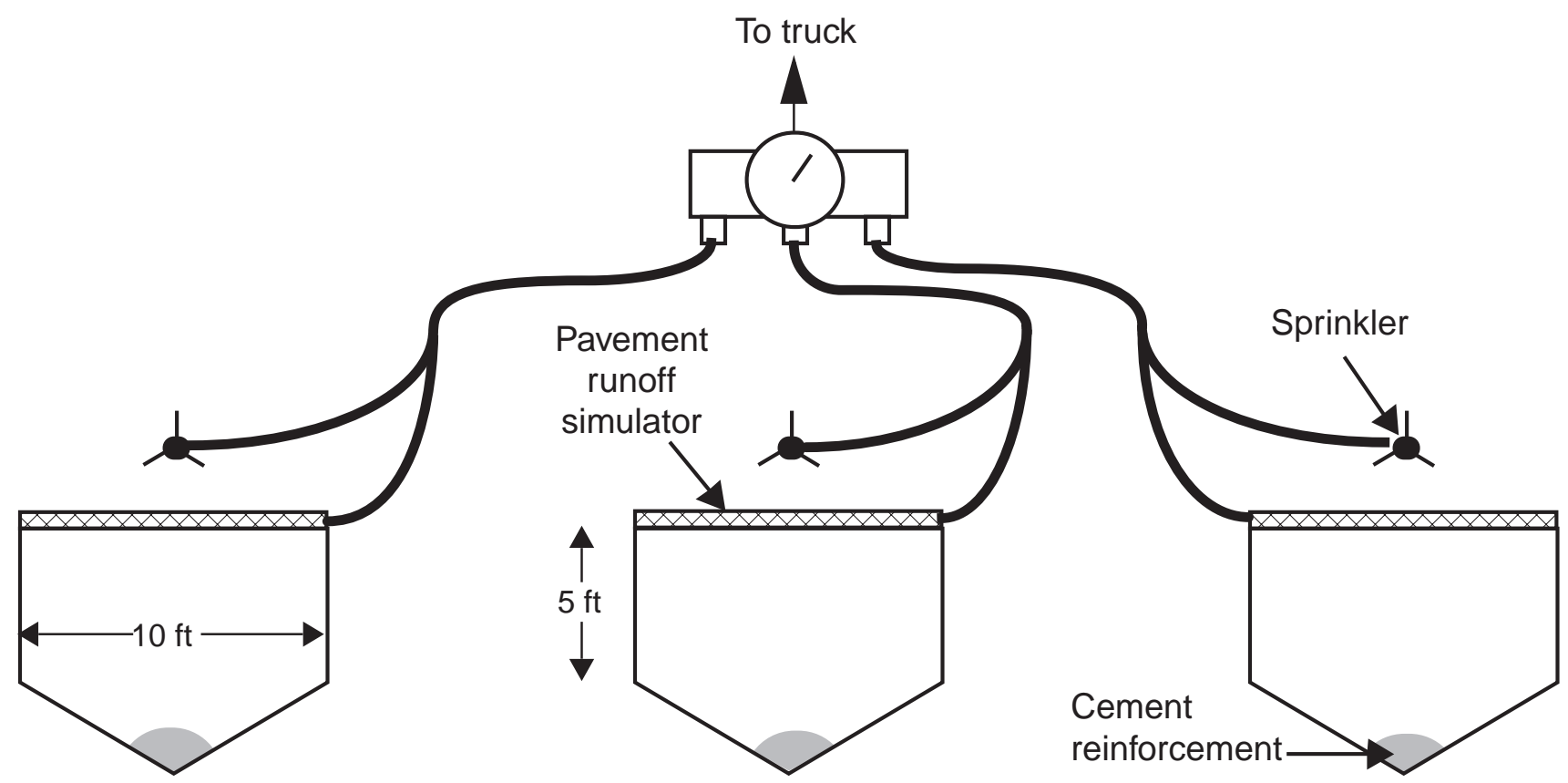

Figure 3. The triplicate simulated rainfall plots. 


\section{Construction of Test Plots}

Three sprayed plots and three control plots were constructed so that the bioassays could be performed in triplicate. The dimensions of the test plots were $10 \mathrm{ft}$ parallel to the road and $5 \mathrm{ft}$ perpendicular to the road, and the plots were spaced $10 \mathrm{ft}$ apart (fig. 3). The plots were bounded by lengths of aluminum sheet metal. At the base of the plots, the sheet metal barrier was angled to form a "V" that funneled runoff into a stainless steel collection bowl. The base of the "V" was reinforced with quick-setting cement in order to prevent erosion of the soil.

Ideally, the rainfall simulation would include simulated rainfall onto the pavement itself, which would then run off the pavement and contribute to the runoff in the test plots. Safety considerations, however, precluded extending the rainfall simulation area out to the crown of the pavement. Instead, the additional runoff into the test plots from the pavement was simulated by calculating the theoretical volume contributed from the centerline of the pavement and sending water at the appropriate rate through a second hose and perforated pipe laid parallel to the pavement along the top of the test plots. This hose was turned on approximately 15 minutes into the simulation in order to simulate the time delay between the start of precipitation and the flow of water off the pavement.

\section{Collection Methods}

Runoff from the test plots was collected in a stainless steel bowl and transferred periodically into a larger stainless steel container with a glass pitcher. On two collection dates, a total of $15 \mathrm{~L}$ (liters) was collected from each test plot. The $15 \mathrm{~L}$ provided water somewhat in excess of the needs for the bioassays, so on one collection date the collection of runoff was stopped at $13 \mathrm{~L}$ in order to shorten the duration of the experiment. At the USGS Oregon District Laboratory, the composited sample was split into representative subsamples with a "cone splitter" (Capel and Larson, 1995), and one subsample was sent to the CVO Laboratory for sediment concentration analysis. Approximately $120 \mathrm{~mL}$ (milliliters) was extracted from another subsample, using a pipette and magnetic stirrer. That volume of water was sent to NWQL for LCFD analysis of glyphosate. The composited sample was then reassembled and passed on to the investigators responsible for the fish and algal bioassays.

During the rainfall simulation experiment, small volumes (less than $100 \mathrm{~mL}$ ) of runoff were extracted periodically from the stream of water coming off of the test plots. This was done with a glass syringe fitted with a teflon plunger. A stainless steel filter assembly was then screwed onto the end of the syringe and the sample was passed through a $0.7 \mu \mathrm{m}$ (micrometer) glass fiber filter into a glass test tube. This processing was done at the site. These samples were chilled for later analysis of diuron and sulfometuron-methyl using ELISA techniques.

\section{Natural Rainfall Experimental Design}

The road shoulder was sprayed again on September 28, 1999, using the same compounds and at the same rates as in the spring. East of Bull Creek, the shoulder was sprayed to Dhooghe Road (a distance of about $0.7 \mathrm{mi}$, fig. 2) and was not sprayed between Dhooghe Road and Colton (a distance of about 1.4mi). Water samples were collected on four dates during fall rainfall: November 16, November 25, December 16, and January 10. On these dates water was collected from the drainage ditch on the north side of the road at the point where it emptied into Bull Creek, from Bull Creek itself about $0.2 \mathrm{mi}$ upstream from the site at Deardorff Road, and from a "control" ditch site that drained a section of the roadway that was not sprayed (fig. 2). The purpose of including the control ditch site was primarily to provide a control for toxicology experiments, similar to those performed with the runoff from the simulated rainfall experiments. Samples also were collected from Bull Creek at its intersection with Highway 211. On November 16, that sample was collected just upstream of the drainage ditch at upstream site 1, but on the last three sample dates that sample was collected downstream of the drainage ditch (downstream site, fig. 2) in order to provide a mass balance check, should the concentrations be high enough. On all four sample dates, the discharge of the sprayed ditch, the control ditch, and Bull Creek were measured, and water samples were collected for the analysis of diuron, bromacil, and sulfometuron-methyl concentration using liquid chromatography/mass spectrometry (LCMS), glyphosate concentration using LCFD, and suspended sediment concentration. A description of the LCMS method used is included as Appendix A. Suspended sediment was measured because glyphosate was expected to be transported primarily in the sediment phase. On November 16 and November 25, some supplementary samples were collected for analysis by ELISA techniques (table 3). 
Table 3. Summary of data collection during natural rainfall, October 1999 through January 2000

[ELISA, enzyme-linked immunosorbent assay; LCFD, liquid chromatography and fluorescence detection; LCMS, liquid chromatography/mass spectrometry; USGS, U.S. Geological Survey]

\begin{tabular}{|c|c|c|c|c|c|}
\hline & October 27 & November 16 & November 25 & December 16 & January 10 \\
\hline Control ditch & & $\begin{array}{l}\text { glyphosate }^{2} \\
\text { diuron }^{1 \& 3} \\
\text { sulfometuron-methyl }^{1 \& 3} \\
\text { bromacil }^{3} \\
\text { suspended sediment } \\
\text { discharge }\end{array}$ & $\begin{array}{l}\text { glyphosate }^{2} \\
\text { diuron }^{1 \& 3} \\
\text { sulfometuron-methyl }^{1 \& 3} \\
\text { bromacil }^{3} \\
\text { suspended sediment }^{4} \\
\text { discharge }\end{array}$ & $\begin{array}{l}\text { glyphosate }^{2} \\
\text { diuron }^{3} \\
\text { sulfometuron-methyl } \\
\text { bromacil }^{3} \\
\text { suspended sediment }^{4} \\
\text { discharge }\end{array}$ & $\begin{array}{l}\text { glyphosate }^{2} \\
\text { diuron }^{3} \\
\text { sulfometuron-methyl }^{3} \\
\text { bromacil }^{3} \\
\text { suspended sediment } \\
\text { discharge }\end{array}$ \\
\hline $\begin{array}{l}\text { Bull Creek, } \\
\text { upstream site (1) }\end{array}$ & $\begin{array}{l}\text { diuron }^{1} \\
\text { sulfometuron-methyl }^{1}\end{array}$ & $\begin{array}{l}\text { glyphosate }^{2} \\
\text { diuron }^{1 \& 3} \\
\text { sulfometuron-methyl }^{1 \& 3} \\
\text { bromacil }^{3} \\
\text { suspended sediment } \\
\text { discharge }\end{array}$ & & & \\
\hline $\begin{array}{l}\text { Bull Creek, } \\
\text { upstream site (2) }\end{array}$ & $\begin{array}{l}\text { diuron }^{1} \\
\text { sulfometuron-methyl }{ }^{1}\end{array}$ & $\begin{array}{l}\text { glyphosate }^{2} \\
\text { diuron }^{1 \& 3} \\
\text { sulfometuron-methyl }^{1 \& 3} \\
\text { bromacil }^{3} \\
\text { suspended sediment } \\
\text { discharge }\end{array}$ & $\begin{array}{l}\text { glyphosate }^{2} \\
\text { diuron }^{1 \& 3} \\
\text { sulfometuron-methyl }^{1 \& 3} \\
\text { bromacil }^{3} \\
\text { suspended sediment } \\
\text { discharge }\end{array}$ & $\begin{array}{l}\text { glyphosate }^{2} \\
\text { diuron }^{3} \\
\text { sulfometuron-methyl }^{3} \\
\text { bromacil }^{3} \\
\text { suspended sediment }^{4} \\
\text { discharge }\end{array}$ & $\begin{array}{l}\text { glyphosate } \\
\text { diuron }^{3} \\
\text { sulfometuron-methyl }^{3} \\
\text { bromacil }^{3} \\
\text { suspended sediment }^{4} \\
\text { discharge }\end{array}$ \\
\hline $\begin{array}{l}\text { Runoff from } \\
\text { road shoulder }\end{array}$ & $\begin{array}{l}\text { diuron }^{1} \\
\text { sulfometuron-methyl }{ }^{1}\end{array}$ & $\begin{array}{l}\text { diuron }^{1} \\
\text { sulfometuron-methyl }{ }^{1}\end{array}$ & $\begin{array}{l}\text { diuron }^{1} \\
\text { sulfometuron-methyl }^{1}\end{array}$ & & $\begin{array}{l}\text { glyphosate }^{2} \\
\text { diuron }^{3} \\
\text { sulfometuron-methyl }^{3} \\
\text { bromacil }^{3}\end{array}$ \\
\hline Sprayed ditch & $\begin{array}{l}\text { diuron }^{1} \\
\text { sulfometuron-methyl }{ }^{1}\end{array}$ & $\begin{array}{l}\text { glyphosate }^{2} \\
\text { diuron }^{1 \& 3} \\
\text { sulfometuron-methyl }^{1 \& 3} \\
\text { bromacil }^{3} \\
\text { suspended sediment } \\
\text { discharge }\end{array}$ & $\begin{array}{l}\text { glyphosate }^{2} \\
\text { diuron }^{1 \& 3} \\
\text { sulfometuron-methyl }^{1 \& 3} \\
\text { bromacil }^{3} \\
\text { suspended sediment } \\
\text { discharge }\end{array}$ & $\begin{array}{l}\text { glyphosate } \\
\text { diuron }^{3} \\
\text { sulfometuron-methyl }^{3} \\
\text { bromacil }^{3} \\
\text { suspended sediment }^{4} \\
\text { discharge }\end{array}$ & $\begin{array}{l}\text { glyphosate }^{2} \\
\text { diuron }^{3} \\
\text { sulfometuron-methyl }^{3} \\
\text { bromacil }^{3} \\
\text { suspended sediment } \\
\text { discharge }\end{array}$ \\
\hline $\begin{array}{l}\text { Bull Creek, } \\
\text { downstream site }\end{array}$ & & & $\begin{array}{l}\text { glyphosate }^{2} \\
\text { diuron }^{1 \& 3} \\
\text { sulfometuron-methyl }^{1 \& 3} \\
\text { bromacil }^{3} \\
\text { suspended sediment } \\
\text { discharge }\end{array}$ & $\begin{array}{l}\text { glyphosate }^{2} \\
\text { diuron }^{3} \\
\text { sulfometuron-methyl }^{3} \\
\text { bromacil }^{3} \\
\text { suspended sediment }^{4} \\
\text { discharge }\end{array}$ & $\begin{array}{l}\text { glyphosate }^{2} \\
\text { diuron }^{3} \\
\text { sulfometuron-methyl }^{3} \\
\text { bromacil }^{3} \\
\text { suspended sediment }^{4} \\
\text { discharge }\end{array}$ \\
\hline
\end{tabular}

${ }^{1}$ ELISA, filtered water, Oregon Department of Environmental Quality Laboratory.

2 LCFD, unfiltered water, USGS National Water Quality Laboratory.

3 LCMS, filtered water, USGS National Water Quality Laboratory.

${ }^{4}$ USGS Cascades Volcano Observatory Laboratory. 
On October 27, while it was raining but discharges in the stream and ditches were still very low, a set of samples was collected from Bull Creek at both upstream sites and from the drainage ditch near Highway 211 for analysis using ELISA techniques. These data were considered exploratory and were used to anticipate the concentrations to be expected in the samples collected later. Several samples were collected from the ditch over a time period spanning approximately 4 hours. In addition, some samples were collected from spouts used in the earlier simulated rainfall experiments. These spouts had collected runoff at the base of the test plots during the simulated rainfall experiments and were left in place to allow the collection of runoff directly from the road shoulder during natural rainfall as well. No discharge measurements were made on this date.

\section{Measurement of Rainfall}

A tipping-bucket rain gage was installed temporarily at a camping and retreat center located approximately $0.3 \mathrm{mi}$ west of the site on Highway 211. Data from the rain gage were transmitted via cellular phone during the months that water samples were collected in order that USGS personnel could monitor rainfall at the site.

\section{Collection Methods}

On November 16, 1999, $30 \mathrm{~L}$ water samples from the stream and drainage ditches were collected into large stainless steel containers. One liter subsamples for analysis by LCMS were extracted from the larger volumes and filtered in the USGS Oregon District Laboratory in Portland, Oregon, with a $0.7 \mu \mathrm{m}$ glass fiber filter before shipping to the NWQL, and the rest of the water was passed on to the investigators responsible for bioassays. On November 25, December 16, and January 10, no water was collected for bioassays, so the samples for LCMS analysis were collected into $3 \mathrm{~L}$ teflon containers and then filtered. On all dates the small-volume samples needed for ELISA analysis were collected into glass test tubes and later filtered in the USGS Oregon District Laboratory with a $0.7 \mu \mathrm{m}$ glass fiber filter. On all dates the $120 \mathrm{~mL}$ samples needed for LCFD analysis of glyphosate were collected as grab samples. On November 16, grab samples for glyphosate analysis were collected at three different points in the cross-section at Bull Creek in order to check for variation across the stream's width.

Drainage ditch samples for the analysis of suspended sediment concentration were grab samples; stream samples were depth- and width-integrated.

\section{RESULTS}

\section{Compound Application Rates}

A direct measurement of compound application rates was made in the spring. Three absorbent sheets were centered $1 \mathrm{ft}$ from the edge of the pavement, two were centered $3 \mathrm{ft}$ from the edge of the pavement, and one sheet was centered $5 \mathrm{ft}$ from the edge of the pavement. The sheet centered $5 \mathrm{ft}$ from the edge of the pavement yielded no detections of the herbicides, indicating that the spray was well-confined to the intended 4-ft swath.

The measured compound application rates were consistently lower than the targeted application rates as supplied by ODOT (table 4). Quality assurance data from the Oregon Department of Agriculture Laboratory indicated that the recoveries of the methods were good: $105 \%$ for bromacil, $67 \%$ for diuron, $90 \%$ for sulfometuron-methyl, and $94 \%$ for glyphosate. The precision of the methods was also good, as indicated by the relative difference in the application rates measured on duplicate or triplicate deposition sheets at 1 and $3 \mathrm{ft}$ from the pavement (35\% or less for all compounds, table 4). The application rates measured at $1 \mathrm{ft}$ and $3 \mathrm{ft}$ from the pavement were

Table 4. Quality assurance data from the Oregon Department of Agriculture Laboratory for the method used to analyze absorbent deposition sheets for the target compounds

[The measured application rate is based on a linear extrapolation of the 1-foot and 3-foot results (not corrected for spike recoveries) to the

4-foot application swath. Targeted application rates of active ingredients in the compounds were supplied by Oregon Department of Transportation (ODOT). $\%$, percent; $\mathrm{kg} \mathrm{AI} / \mathrm{ha}$, kilograms active ingredient per hectare ]

\begin{tabular}{lccccr}
\hline \multicolumn{1}{c}{$\begin{array}{c}\text { Compound } \\
\text { (formulation) }\end{array}$} & $\begin{array}{c}\mathbf{1} \text { foot } \\
\text { relative } \\
\text { difference (\%) }\end{array}$ & $\begin{array}{c}\text { 3 foot } \\
\text { relative } \\
\text { difference (\%) }\end{array}$ & $\begin{array}{c}\text { Laboratory } \\
\text { spike recoveries } \\
\text { (\%) }\end{array}$ & $\begin{array}{c}\text { Measured } \\
\text { rate } \\
\text { (kg Al/ha) }\end{array}$ & $\begin{array}{c}\text { Targeted rate } \\
\text { (kg Al/ha) }\end{array}$ \\
\hline Diuron (Krovar) & 7 & 23 & 67 & 0.91 & 1.34 \\
Bromacil (Krovar) & 4 & 32 & 105 & 93 & .93 \\
Sulfometuron-methyl (Oust) & 18 & 13 & 90 & .15 & .26 \\
Glyphosate (Roundup) & 12 & 35 & 94 & 1.45 & 2.24 \\
\hline
\end{tabular}


linearly extrapolated over the 4-ft swath that was sprayed, and the reported application rate in table 4 is the aerial average based on that linear extrapolation. Measured application rates were not adjusted for the recoveries in the laboratory spikes. Diuron and bromacil were measured at nearly the same application rate on the road shoulder $(0.9 \mathrm{~kg} / \mathrm{ha})$, in spite of the differences in their recoveries in laboratory spikes, but consistent with the fact that they are found in equal proportion in the source compound, Krovar, suggesting that either the recovery of diuron was better than indicated by the laboratory spikes, or that the recovery of bromacil was worse. Considering that all four compounds were measured at an application rate over $30 \%$ less than the targeted rate, however, there is a high probability that ODOT operations resulted in an application rate of these compounds that was lower than the targeted rate. The measured application rates were used in the calculations of herbicide removal.

\section{Quality of Herbicide Concentration Data}

The precision of the LCMS, ELISA, and LCFD data was assessed with replicate samples (tables 5, 6, and 7). Replication by LCMS and ELISA is generally good, with a relative difference generally $33 \%$ or less. The replication of the LCFD method was very good, showing no relative difference between triplicate samples.

The accuracy of the LCMS data was assessed directly with spiked environmental samples. One set of samples was collected on August 31, 1999, for the sole purpose of providing spiked samples for analysis of method accuracy. The native water was collected from Bull Creek. Six samples were filtered and then spiked to a concentration of $0.375 \mu \mathrm{g} / \mathrm{L}$ with solutions supplied by the NWQL. The spiked samples were analyzed in triplicate, one set immediately after collection and one set 30 days later. The latter set of samples was chilled at less than $4^{\circ} \mathrm{C}$ (degrees Celsius) for the 30 days prior to analysis. Two more samples were collected in the fall and spiked: one from the control ditch on November 16, and one from Bull Creek on November 25. The recoveries from all of the spiked environmental samples are compiled in table 8 .

The analyses of the spiked samples showed substantial overall variability in the accuracy that could be expected. The samples collected on August 31 for the sole purpose of defining accuracy yielded recoveries from $65 \%$ to $92 \%$ for diuron, from $20 \%$ to $65 \%$ for bromacil, and from $113 \%$ to $169 \%$ for sulfometuron-methyl.
Table 5. Replicate values: LCMS data

[LCMS, liquid chromatography/mass spectrometry; $\mu \mathrm{g} / \mathrm{L}$, micrograms per liter; \%, percent; <, less than; - , undefined]

\begin{tabular}{|c|c|c|c|}
\hline Date & Location & $\begin{array}{c}\text { Concentration } \\
(\mu \mathrm{g} / \mathrm{L})\end{array}$ & $\begin{array}{c}\text { Relative } \\
\text { difference } \\
(\%)\end{array}$ \\
\hline \multicolumn{4}{|c|}{ Diuron } \\
\hline 11/16/1999 & Control ditch & $\begin{array}{r}0.054 \\
.040\end{array}$ & 30 \\
\hline 11/16/1999 & Sprayed ditch & $\begin{array}{l}.085 \\
.092\end{array}$ & 7.9 \\
\hline $11 / 25 / 1999$ & Bull Creek & $\begin{array}{l}<.074 \\
<.074\end{array}$ & - \\
\hline $11 / 25 / 1999$ & Control ditch & $\begin{array}{l}.11 \\
.10\end{array}$ & 10 \\
\hline $11 / 25 / 1999$ & Sprayed ditch & $\begin{array}{l}.67 \\
.60\end{array}$ & 11 \\
\hline $12 / 16 / 1999$ & Sprayed ditch & $\begin{array}{l}.26 \\
.32\end{array}$ & 21 \\
\hline \multicolumn{4}{|c|}{ Bromacil } \\
\hline $11 / 16 / 1999$ & Control ditch & $\begin{array}{l}.37 \\
.25\end{array}$ & 39 \\
\hline 11/16/1999 & Sprayed ditch & $\begin{array}{l}.45 \\
.53\end{array}$ & 16 \\
\hline $11 / 25 / 1999$ & Bull Creek & $\begin{array}{l}<.075 \\
<.075\end{array}$ & - \\
\hline $11 / 25 / 1999$ & Control ditch & $\begin{array}{l}.28 \\
.20\end{array}$ & 33 \\
\hline $11 / 25 / 1999$ & Sprayed ditch & $\begin{array}{l}<.075 \\
<.075\end{array}$ & - \\
\hline $12 / 16 / 1999$ & Sprayed ditch & $\begin{array}{l}.92 \\
.98\end{array}$ & 6.3 \\
\hline \multicolumn{4}{|c|}{ Sulfometuron-methyl } \\
\hline 11/16/1999 & Control Ditch & $\begin{array}{l}<.036 \\
<.036\end{array}$ & - \\
\hline 11/16/1999 & Sprayed ditch & $\begin{array}{l}.104 \\
.105\end{array}$ & 1.0 \\
\hline $11 / 25 / 1999$ & Bull Creek & $\begin{array}{l}<.036 \\
<.036\end{array}$ & - \\
\hline $11 / 25 / 1999$ & Sprayed ditch & $\begin{array}{l}1.13 \\
1.01\end{array}$ & 11 \\
\hline $11 / 25 / 1999$ & Control ditch & $\begin{array}{l}<.036 \\
<.036\end{array}$ & - \\
\hline $12 / 16 / 1999$ & Sprayed ditch & $\begin{array}{l}.35 \\
.41\end{array}$ & 16 \\
\hline
\end{tabular}


Table 6. Replicate values: ELISA data

[ELISA, enzyme-linked immunosorbent assay; $\mu \mathrm{g} / \mathrm{L}$, micrograms per liter; $\%$, percent; <, less than; - , undefined]

\begin{tabular}{|c|c|c|c|}
\hline Date & Location & $\begin{array}{c}\text { Concentration } \\
(\mu \mathrm{g} / \mathrm{L})\end{array}$ & $\begin{array}{c}\text { Relative } \\
\text { difference } \\
(\%)\end{array}$ \\
\hline \multicolumn{4}{|c|}{ Diuron } \\
\hline $5 / 20 / 1999$ & Plot 1 & $\begin{array}{l}976 \\
835\end{array}$ & 16 \\
\hline 11/25/1999 & Bull Creek & $\begin{array}{r}<.02 \\
\quad .023\end{array}$ & - \\
\hline 11/25/1999 & Control ditch & $\begin{array}{l}.151 \\
.132\end{array}$ & 13 \\
\hline 11/25/1999 & Sprayed ditch & $\begin{array}{l}.922 \\
.918\end{array}$ & 0.4 \\
\hline \multicolumn{4}{|c|}{ Sulfometuron-methyl } \\
\hline $5 / 20 / 1999$ & Plot 1 & $\begin{array}{l}534 \\
545\end{array}$ & 2.0 \\
\hline 6/3/1999 & Plot 2 & $\begin{array}{r}16.4 \\
9.3 \\
10.3\end{array}$ & 59 \\
\hline 11/16/1999 & Control ditch & $\begin{array}{l}<.14 \\
<.14\end{array}$ & - \\
\hline 11/16/1999 & Sprayed ditch & $\begin{array}{l}.135 \\
.122\end{array}$ & 10 \\
\hline
\end{tabular}

The water collected from the control ditch and spiked on November 16, however, yielded much lower recoveries for diuron and sulfometuron-methyl, about $40 \%$ in both cases. On November 25, water collected from Bull Creek and spiked yielded much higher recoveries-over $200 \%$ for diuron and over $300 \%$ for sulfometuron-methyl. The laboratory calibration standards show the equipment operating within the acceptable range on both dates but, of the 53 analytes in the spike solution provided by the NWQL, almost all had very low recoveries in the control ditch water on November 16 (median recovery 8\%) and much higher recoveries in the Bull Creek water on November 25 (median recovery 60\%). (Bromacil did not behave

Table 7. Replicate values: LCFD data [LCFD, liquid chromatography and fluorescence detection; $\mu \mathrm{g} / \mathrm{L}$, micrograms per liter; $\%$, percent]

\begin{tabular}{cccc}
\hline Date & Location & $\begin{array}{c}\text { Concentration } \\
(\mu \mathbf{g} / \mathbf{L})\end{array}$ & $\begin{array}{c}\text { Relative } \\
\text { difference } \\
(\%)\end{array}$ \\
\hline \multirow{4}{*}{ 6/3/1999 } & \multicolumn{2}{c}{ Glyphosate } \\
& Plot 2 & 21 & 0 \\
& & 21 & \\
& & 21 & \\
\hline
\end{tabular}

similarly to most of the other compounds; its recoveries were $93-101 \%$ on November 16 and $72 \%$ on November 25.) It is likely, therefore, that most of the difference in recovery can be attributed to characteristics of the native water, rather than differences in equipment, internal standards, analyst, or any other features of the analytical procedure that would differentiate the two samples. It is logical to assume that characteristics of the control ditch water that interfered with compound recovery in the November 16 spike also limited the recoveries of diuron and sulfometuron-methyl in other samples from the drainage ditches collected on other dates. The recovery of bromacil does not appear to have been similarly affected.

A few samples collected on November 16th and November 25th were split and analyzed by both the ELISA and LCMS methods. The results of these comparisons are compiled in table 9 . These comparisons show the ELISA diuron values are $35 \%$ and $45 \%$ higher in samples collected from the control ditch and the sprayed ditch, respectively, on November 25. The only detection of sulfometuron-methyl, in the sprayed ditch on November 16, shows the ELISA values to be about $23 \%$ higher than the LCMS values. Given that the expected recoveries of these two compounds in water collected from the drainage ditches can be about $40 \%$, these comparisons indicate that the ELISA values probably do not overestimate concentrations and, indeed, may underestimate concentrations. The accuracy of the ELISA data could not be assessed independently with the spiked environmental samples, because the spiking solution supplied by the NWQL contained several urea and sulfonyl urea herbicides, and the ELISA methods are not compound-specific under those conditions.

The determination of the concentration of synthetic organic compounds in environmental water samples, particularly at low (parts per billion) levels, is a notoriously difficult analytical problem. The assessment of data quality presented here is based on a relatively ambitious quality assurance dataset of spikes and replicates relative to the number of environmental samples, and yet it is still inadequate to place well-defined limits on the precision and accuracy of the data. As a result, it is important to recognize that all of the data presented are semiquantitative in nature and that interpretations should take this into account. These data can be relied on only for orderof-magnitude representations of concentrations, and possibly for trends. 
Table 8. Spike Recoveries of LCMS data

[LCMS, liquid chromatography/mass spectrometry. All data are for duplicate or triplicate samples. For samples collected on 8/31/1999, (a) indicates samples analyzed immediately, (b) indicates samples analyzed after 30 days. Samples collected on 11/16 and 11/25/1999 were analyzed immediately. Samples were collected, spiked, and analyzed in triplicate on $8 / 31 / 1999$ or duplicate on all other dates.]

\begin{tabular}{|c|c|c|}
\hline & $\begin{array}{c}\text { Sample } \\
\text { date }\end{array}$ & $\begin{array}{c}\text { Recoveries } \\
(\%)\end{array}$ \\
\hline \multicolumn{3}{|c|}{ Diuron } \\
\hline (a) & 8/31/1999 & $\begin{array}{l}92 \\
75 \\
65\end{array}$ \\
\hline (b) & $8 / 31 / 1999$ & $\begin{array}{l}88 \\
88 \\
80\end{array}$ \\
\hline & 11/16/1999 & $\begin{array}{l}38 \\
43\end{array}$ \\
\hline & $11 / 25 / 1999$ & $\begin{array}{l}211 \\
224\end{array}$ \\
\hline \multicolumn{3}{|c|}{ Bromacil } \\
\hline (a) & $8 / 31 / 1999$ & $\begin{array}{l}45 \\
20 \\
43\end{array}$ \\
\hline (b) & $8 / 31 / 1999$ & $\begin{array}{l}61 \\
64 \\
65\end{array}$ \\
\hline & 11/16/1999 & $\begin{array}{r}93 \\
101\end{array}$ \\
\hline & $11 / 25 / 1999$ & $\begin{array}{l}72 \\
72\end{array}$ \\
\hline \multicolumn{3}{|c|}{ Sulfometuron-methyl } \\
\hline (a) & $8 / 31 / 1999$ & $\begin{array}{l}169 \\
127 \\
113\end{array}$ \\
\hline (b) & 8/31/1999 & $\begin{array}{l}130 \\
132 \\
119\end{array}$ \\
\hline & 11/16/1999 & $\begin{array}{l}37 \\
43\end{array}$ \\
\hline & $11 / 25 / 1999$ & $\begin{array}{l}315 \\
347\end{array}$ \\
\hline
\end{tabular}

\section{Simulated Rainfall Experiments}

The instantaneous concentrations of sulfometuron-methyl and diuron obtained from ELISA analysis during each of the three simulated rainfall events on May 20, May 26, and June 3, 1999, is shown in figure 4.
These instantaneous concentrations were not designed to be an equal-volume representation of the final composited sample, for two reasons. First, the timing of the collection of the small-volume samples for this analysis was determined by how fast the processing proceeded in the field, and could not be established ahead of time; as a result, the time increment between samples was not consistent. Additionally, the time to collect the total volume of runoff from each plot varied, so the number of samples collected from each plot during each event was not the same.

The typical pattern of the instantaneous concentrations exhibited random variability rather than a trend with time; therefore, attempting to fit the concentration data with a smooth time-varying function to obtain a volume-weighted concentration for the composited sample was not justified. The median concentration, also shown in figure 4, is a better representation of the concentration in the runoff composited over the event.

The event-mean concentration of glyphosate in the composited runoff is also shown in figure 4 . These are not instantaneous data, but rather are based on subsamples of the composited runoff, collected after the experiment had ended.

The event-mean or event-median concentration can be converted to a fraction of the target compound removed by calculating the mass in $15 \mathrm{~L}$ of runoff and dividing by the amount of compound applied to each plot. The measured rather than targeted application rates were used in these calculations. The duration of rainfall required to produce $15 \mathrm{~L}$ of runoff varied according to the amount of infiltration (table 10) which was inconsistent, but the duration was not longer than could reasonably be expected to occur under natural conditions ( $0.5 \mathrm{hr}$ to $1.4 \mathrm{hr}$ on May 20 and June 3). Infiltration was particularly high on the sample date 1 week after compound application (May 26), such that between 0.7 and $1.9 \mathrm{hr}$ was required to collect a slightly smaller volume of runoff $(13 \mathrm{~L})$. The higher infiltration rates on May 26 are hard to explain, although the Glenn County experiments also showed variable infiltration rates (table 2). It is also possible that water delivery was influenced by inconsistent operation of the ODOT water supply pump and was overestimated on May 26, resulting in overestimated infiltration as well. Infiltration also was lower on plot 1 on every event date (table 10), probably because plot 1 had no vegetative cover while the other two plots each had small amounts of vegetative cover. 
Table 9. Replicate values: Comparison of LCMS \& ELISA data [LCMS, liquid chromatography/mass spectrometry;

ELISA, enzyme-linked immunosorbent assay;

ELISA/LCMS is the mean value of the ratio of the concentrations determined by the two methods. $\mu \mathrm{g} / \mathrm{L}$, micrograms per liter; <, less than; - undefined]

\begin{tabular}{|c|c|c|c|c|}
\hline Date & Location & $\begin{array}{l}\text { Data } \\
\text { type }\end{array}$ & $\begin{array}{c}\text { Concen- } \\
\text { tration } \\
(\mu \mathrm{g} / \mathrm{L})\end{array}$ & $\begin{array}{l}\text { ELISA/ } \\
\text { LCMS }\end{array}$ \\
\hline \multicolumn{5}{|c|}{ Diuron } \\
\hline \multirow[t]{2}{*}{ 11/25/1999 } & Bull Creek & ELISA & $\begin{array}{r}<0.02 \\
.023\end{array}$ & - \\
\hline & & LCMS & $\begin{array}{l}<.074 \\
<.074\end{array}$ & \\
\hline \multirow[t]{2}{*}{$11 / 25 / 1999$} & Control ditch & ELISA & $\begin{array}{l}.151 \\
.132\end{array}$ & 1.35 \\
\hline & & LCMS & $\begin{array}{l}.11 \\
.10\end{array}$ & \\
\hline \multirow[t]{2}{*}{$11 / 25 / 1999$} & Sprayed ditch & ELISA & $\begin{array}{l}.922 \\
.918\end{array}$ & 1.45 \\
\hline & & LCMS & $\begin{array}{l}.67 \\
.60\end{array}$ & \\
\hline \multicolumn{5}{|c|}{ Sulfometuron-methyl } \\
\hline \multirow[t]{2}{*}{ 11/16/1999 } & Control ditch & ELISA & $\begin{array}{l}<.14 \\
<.14\end{array}$ & - \\
\hline & & LCMS & $\begin{array}{l}<.036 \\
<.036\end{array}$ & \\
\hline \multirow[t]{2}{*}{ 11/16/1999 } & Sprayed ditch & ELISA & $\begin{array}{l}.135 \\
.122\end{array}$ & 1.23 \\
\hline & & LCMS & $\begin{array}{l}.104 \\
.105\end{array}$ & \\
\hline
\end{tabular}

Removal of the compounds within 24 hours of application, based on the event-median concentrations, was greatest for sulfometuron-methyl (3.3-7.1\%), and less for diuron and glyphosate (1.7-2.7\% and $0.9-2.1 \%$ for diuron and glyphosate, respectively). Thus, it appears that even though sulfometuronmethyl is applied at a much lower rate than the other compounds, it is mobilized more easily in runoff, and therefore environmental concentrations may not be as low when compared to other compounds as would be expected based on application rates alone. The difference between sulfometuron-methyl and diuron is consistent with their relative affinities for soil organic matter: $\mathrm{K}_{\mathrm{oc}}=78$ and 480 for sulfometuron-methyl and diuron, respectively (Wauchope, et al., 1992). At much lower concentrations, glyphosate $\left(\mathrm{K}_{\mathrm{oc}}=24,000\right)$ is known to be transported primarily in the solid phase.

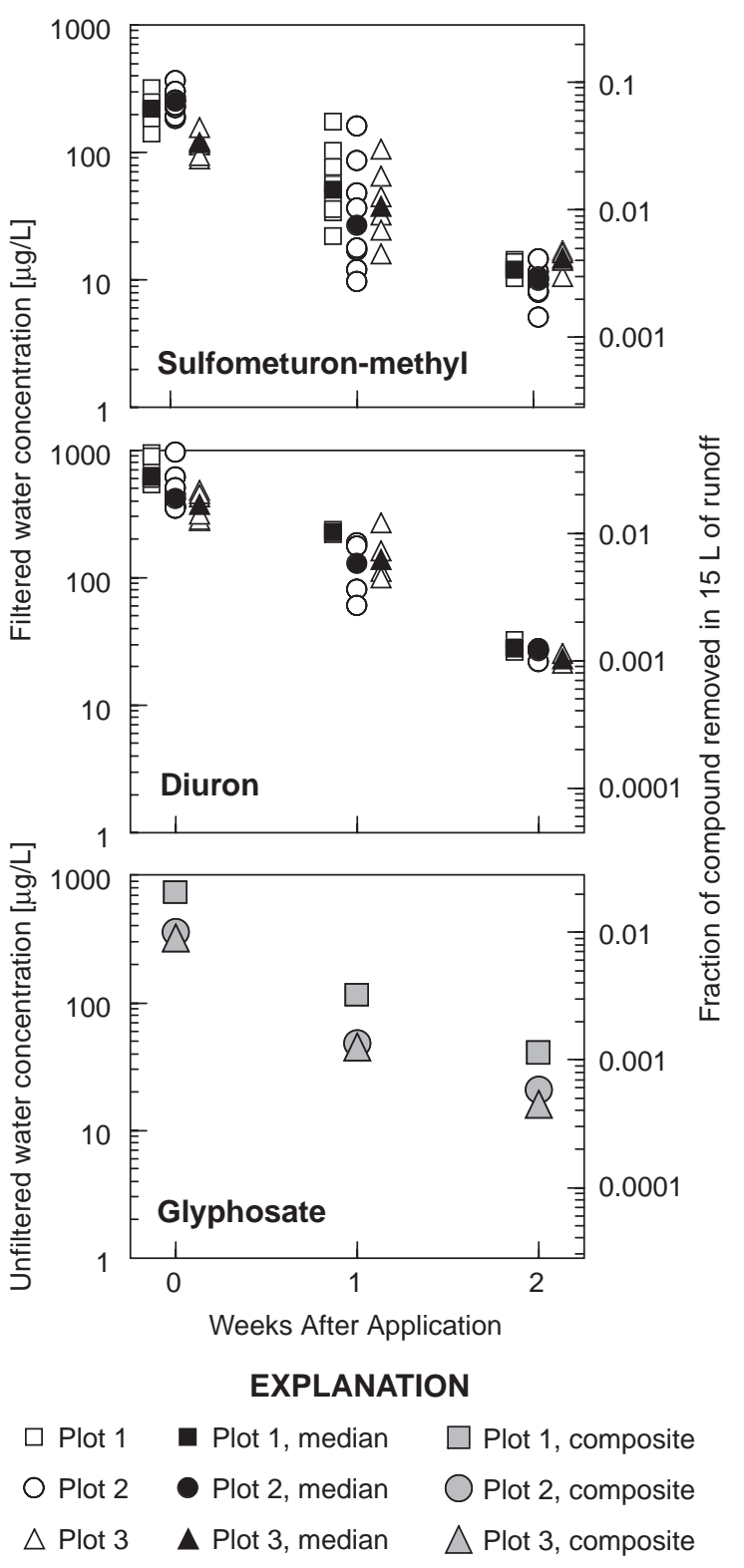

Figure 4. Herbicide concentrations in runoff from test plots on the road shoulder near the intersection of Bull Creek and Highway 211, Oregon. Open symbols are instantaneous values obtained at unspecified intervals over the simulation event. The fraction of the compound removed is based on the median or composite value on each simulation date.

At the concentrations measured in these simulated rainfall experiments (300-700 $\mu \mathrm{g} / \mathrm{L}$ of glyphosate and 8-27 mg/L of fine sediment, table 11), however, most of the glyphosate must be in dissolved form.

The fraction of the compound removed in the simulated event 1 week after compound application decreased dramatically from the first simulated event, followed by a smaller decrease in the fraction removed between 1 week and 2 weeks after compound application. 
Table 10. Fraction of water lost to infiltration during simulated rainfall experiments

\begin{tabular}{cccc}
\hline $\begin{array}{c}\text { Weeks after } \\
\text { compound } \\
\text { application }\end{array}$ & Plot 1 & Plot 2 & Plot 3 \\
\hline 0 & 0.55 & 0.76 & 0.75 \\
1 & .78 & .92 & .94 \\
2 & .60 & .89 & .88 \\
\hline
\end{tabular}

The only natural rainfall that occurred during the 2 -week time frame was 0.02 inches 6 days after compound application, and 0.22 inches (over several hours) 11 days after compound application. While the 0.22 inches of rainfall between the second and third sample dates might have been enough to transport some of the herbicide below the soil surface via infiltration, it is unlikely that the rainfall between the first and second sample date had any effect at all. Therefore, the changes in concentration and the amount of compound removed between the day after application and 1 week after application are most likely due to a decrease in the readily mobilized fraction of the compound, and, to a lesser extent, degradation. The $\mathrm{K}_{\mathrm{oc}}$ values for these compounds indicate that even sulfometuron-methyl and diuron, though clearly more hydrophilic than glyphosate, will still partition to the soil organic matter. Half-lives of the target compounds are 20 days, 47 days, and 90 days for sulfometuron-methyl, glyphosate, and diuron, respectively (Wauchope, et al., 1992). The decrease in the removal of these compounds after 1 and then 2 weeks is much greater than can be explained by degradation alone. Sorption processes are complex, but a loss of the readily mobilized fraction between rainfall events could be attributed to a slow desorption of the solid-phase fraction that cannot fully replace the compound in the soil moisture between rainfall events.

The event-mean concentration in runoff of each of the herbicides declined by as much as 1.5 orders of magnitude from the first day after application to the second week after application (fig. 4). The median concentrations of diuron measured by ELISA ranged from 372 to $613 \mu \mathrm{g} / \mathrm{L}$ on the first day after application, and from 23 to $28 \mu \mathrm{g} / \mathrm{L} 2$ weeks after application.

Concentrations of glyphosate were of a similar magnitude, and ranged from 736 to $323 \mu \mathrm{g} / \mathrm{L}$ on the first day after application and from 16 to $41 \mu \mathrm{g} / \mathrm{L}$ 2 weeks after application. The concentration of gly- phosate in the runoff from plot 1 is consistently higher than in the runoff from the other two plots. Quality assurance samples indicated that the glyphosate analysis was precise, and this difference may be real. Plot 1 was characterized by lower infiltration than the other two plots (table 10), and sediment data from two of the collection dates show concentrations of fine sediment in the runoff from test plot 1 that were two to three times higher than concentrations in the runoff from test plot 3 (table 11). The higher sediment concentration at test plot 1 would indicate a higher solid-phase concentration of glyphosate in the runoff from that plot; at these concentrations, however, most of the total glyphosate in the runoff must be in the dissolved phase so the higher sediment concentration at test plot 1 cannot, by itself, account for the higher concentration of glyphosate at that test plot. The fact that test plots 2 and 3 were more vegetated than test plot 1 may indicate that there were more silts and clays mixed in with the sand and gravel at those two test plots, and therefore more capacity to adsorb the glyphosate and retain it in the soil matrix.

Sulfometuron-methyl concentrations were the lowest of the three target compounds, consistent with its lower application rate, and ranged from 119 to $253 \mu \mathrm{g} / \mathrm{L}$ on the day after application, and from $10-15 \mu \mathrm{g} / \mathrm{L} 2$ weeks later. As discussed previously, however, the amount of this compound removed as a percentage of the amount applied is greater than for either diuron or glyphosate, indicating that sulfometuron-methyl is more readily mobilized than the other two compounds.

The results of these simulated rainfall experiments confirm that the herbicides applied by ODOT behave in a manner broadly similar to that observed in the Glenn County, California, study that examined roadside applications. Quantitative comparisons are difficult because of site-specific differences, particularly the percent runoff, and differences in the amount of antecedent precipitation on each test plot. The concentrations of diuron observed in this study are lower, a result that is attributable to the fact that the application rate of diuron in this study $(0.9 \mathrm{~kg} / \mathrm{ha})$ was approximately one-fourth of the application rate used in the Glenn County study (3.6 kg/ha). Additionally, in this study the concentrations in filtered water are reported as compared to unfiltered water in the Glenn County study; therefore the concentrations in filtered water reported in this study could be somewhat lower than concentrations in an unfiltered sample 
Table 11. Concentration of fine-grained sediment in the runoff collected from the test plots

[Units are in milligrams per liter; - , data not available]

\begin{tabular}{cccc}
\hline $\begin{array}{c}\text { Weeks after } \\
\text { compound } \\
\text { application }\end{array}$ & Plot 1 & Plot 2 & Plot 3 \\
\hline 0 & 27 & 17 & 8 \\
1 & 20 & 10 & 8 \\
2 & - & 43 & 12 \\
\hline
\end{tabular}

resulting from the same application rate of diuron. Diuron is, however, a hydrophilic compound, and its concentration in runoff and stream samples is composed primarily of the dissolved phase.

These experiments have shown that a heavy rainstorm occurring soon after application at the typical Willamette Valley site could generate concentrations in the runoff leaving the road shoulder of nearly $1 \mathrm{mg} / \mathrm{L}$ glyphosate and diuron, and concentrations on the order of a few hundred micrograms per liter of sulfometuron-methyl. During natural rainfall, some of the runoff directly from the road shoulder infiltrates into the ground once it leaves the shoulder, and the rest is diluted with water from the surrounding landscape; these concentrations overestimate, therefore, the concentration in the ditches that carry the road runoff to the stream. Furthermore, not only the concentration in the ditch but also the discharge of the ditch determines the severity of the impact of the road drainage on the stream. For this reason, data collection proceeded in the fall during natural rainfall, in order to measure the loadings of the target compounds to Bull Creek under realistic conditions.

\section{Data Collection During Natural Rainfall}

The road shoulders were sprayed again on September 28, 1999, using the same compounds, rates, and procedures as in the spring. The first significant rainfall occurred on October 6 , about 1 week later (fig. 5). At the time of the first reconnaissance sampling on October 27, an accumulation of 2.7 inches of rain had fallen since the road shoulders were sprayed, but the discharge in the drainage ditches was still very low, and, in fact, discharges of Bull Creek and the drainage ditches did not increase substantially until the sample collection effort on November 25 (table 12).

The drainage ditch draining the section of the roadway that had been sprayed (designated the "sprayed" ditch, although the ditch itself was not sprayed, just the adjacent shoulder) captured very little water from any land area other than the roadway itself, and remained at a very low discharge $(0.1-0.3 \%$ of Bull Creek discharge) through the 3-month sampling period. The sprayed ditch, therefore, carried largely undiluted runoff from the road shoulder directly to Bull Creek. In contrast, the drainage ditch draining the section of the roadway that was left unsprayed on September 28 (designated the control ditch) clearly captured quite a bit of water from the surrounding landscape and behaved much like a small stream itself, with a discharge that increased through the 3-month sampling period and was measured to be $5-17 \%$ of the discharge of Bull Creek. Most of the water carried by the control ditch was diverted north away from Highway 211 to Milk Creek between Hult and Deardorff Road, and did not flow into the upstream end of the sprayed ditch (fig. 2).

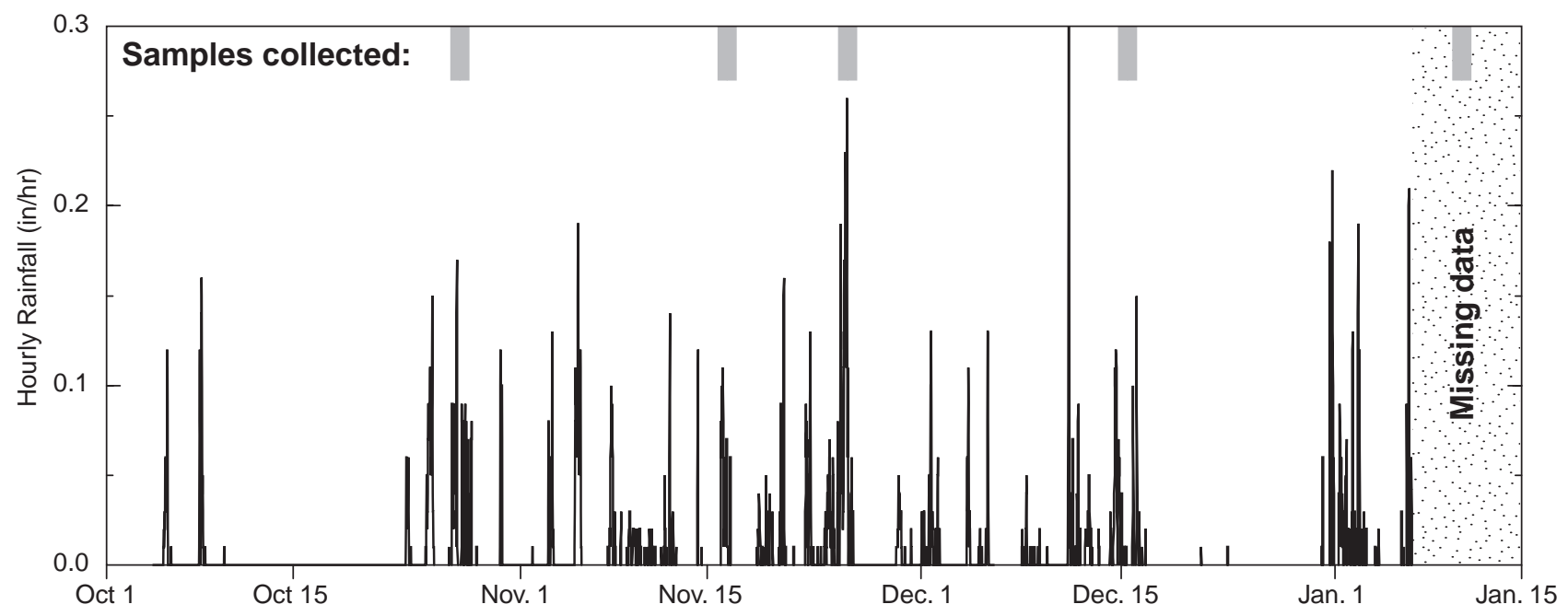

Figure 5. Rainfall data from Camp Adams rain gage. Hourly rainfall is a running average of four 15-minute intervals. 
Table 12. Accumulated rainfall and discharge in the stream and drainage ditches on each of the fall sampling dates [in, inches; $\mathrm{ft}^{3} / \mathrm{s}$, cubic feet per second; - , data not available]

\begin{tabular}{|c|c|c|c|c|}
\hline Sample date & $\begin{array}{c}\text { Accumulated } \\
\text { rainfall since } \\
9 / 28 / 99 \text { (in) }\end{array}$ & $\begin{array}{l}\text { Bull Creek discharge } \\
\qquad\left(\mathrm{ft}^{3} / \mathrm{s}\right)\end{array}$ & $\begin{array}{l}\text { Sprayed ditch } \\
\text { discharge }\left(\mathrm{ft}^{3} / \mathrm{s}\right)\end{array}$ & $\begin{array}{c}\text { Control ditch } \\
\text { discharge }\left(\mathrm{ft}^{3} / \mathrm{s}\right)\end{array}$ \\
\hline $10 / 27 / 99$ & 2.67 & - & - & - \\
\hline $11 / 16 / 99$ & 6.42 & 1.2 & 0.003 & 0.2 \\
\hline $11 / 25 / 99$ & 9.19 & 11 & .022 & .67 \\
\hline $12 / 16 / 99$ & 14.1 & 12.6 & .014 & .67 \\
\hline $1 / 10 / 00$ & 18.6 & 19.7 & .023 & 1.32 \\
\hline
\end{tabular}

The fall diuron data show that concentrations in the runoff directly from the road shoulder remained in the $1-10 \mu \mathrm{g} / \mathrm{L}$ range throughout the 3 -month sampling period (fig. 6). The concentration in the sprayed ditch was similar to that coming off the road shoulder on October 27, indicating that the ditch carried largely undiluted runoff. By the 10th of January, a concentration of $5.1 \mu \mathrm{g} / \mathrm{L}$ was measured in the runoff from the road shoulder, and $0.27 \mu \mathrm{g} / \mathrm{L}$ in the sprayed ditch, indicating that as the fall rainy season proceeded more dilution of the runoff from the shoulder was occurring.

Only in October, however, when the stream discharge was still at late-summer low levels, was diuron detected in Bull Creek, at concentrations between 0.1 and $0.3 \mu \mathrm{g} / \mathrm{L}$. Notably, on that date diuron was detected both directly upstream of the sprayed ditch at Highway 211 (upstream site 1), and $0.2 \mathrm{mi}$ upstream of the intersection with Highway 211 (upstream site 2), at a point where the stream could not have been influenced by ODOT's spray operations (fig. 6). A mass balance calculation for the October sampling, using the discharge in the sprayed ditch on November 16 as an upper limit, confirmed that the load contributed by the ditch would not have resulted in a detectable concentration in Bull Creek (approximately $0.0008 \mu \mathrm{g} / \mathrm{L}$ ); therefore, another, unidentified, upstream source is indicated. No diuron was detected in Bull Creek on any of the subsequent sample dates. Mass balance calculations were consistent with that result in that they showed that the load to Bull Creek from the sprayed ditch was too low to result in detectable concentrations in the stream during the November to January time period (theoretical concentrations would have been in the range of 0.001 to $0.003 \mu \mathrm{g} / \mathrm{L}$ ).

Sulfometuron-methyl was detected in the 0.1 to $1 \mu \mathrm{g} / \mathrm{L}$ range in the sprayed ditch throughout the 3-month sampling period, but was never detected in the control ditch or in the stream. Mass balance calculations indicated that only at the highest concentra- tions measured in the sprayed ditch on November 25 was the ditch possibly carrying enough load to bring stream concentrations up to detectable levels - around $0.06 \mu \mathrm{g} / \mathrm{L}$. Concentrations so close to the detection limit are likely to be transient, however, and the stream sample collected downstream of the drainage ditch on November 25 did not show detectable levels of sulfometuron-methyl. The similarity of the concentrations in the sprayed ditch and in the runoff from the road shoulder in October and November again indicates that the water in the sprayed ditch was largely undiluted runoff from the road shoulder, with very little extra water captured from the surrounding landscape (fig. 6).

The concentrations of herbicides in the control ditch, and the comparison with concentrations in the sprayed ditch, indicated that the largest source of herbicides in the control ditch was the surrounding landscape and not ODOT's operations. Because the road shoulders adjacent to the control ditch were not sprayed in the fall, and given the amount of dilution of road runoff occurring in the control ditch, it was not expected that diuron would be found at detectable concentrations in the control ditch. If, for example, the control ditch were assumed to carry the same load of diuron as the sprayed ditch, but at its much higher discharge, then only on the October 27 sample date would diuron concentrations still, theoretically, be above the analytical method's detection limit. The fact that diuron was measured in the control ditch throughout the 3-month sampling period is, therefore, probably indicative of diuron flowing into that roadside ditch from the surrounding landscape. The same argument can be made regarding the appearance of bromacil in the control ditch. Concentrations of bromacil were of similar magnitude in the control ditch and in the sprayed ditch; in fact, concentrations of bromacil in the control ditch were similar in magnitude to the concentration of bromacil measured in the direct runoff from the roadway (fig. 6). 

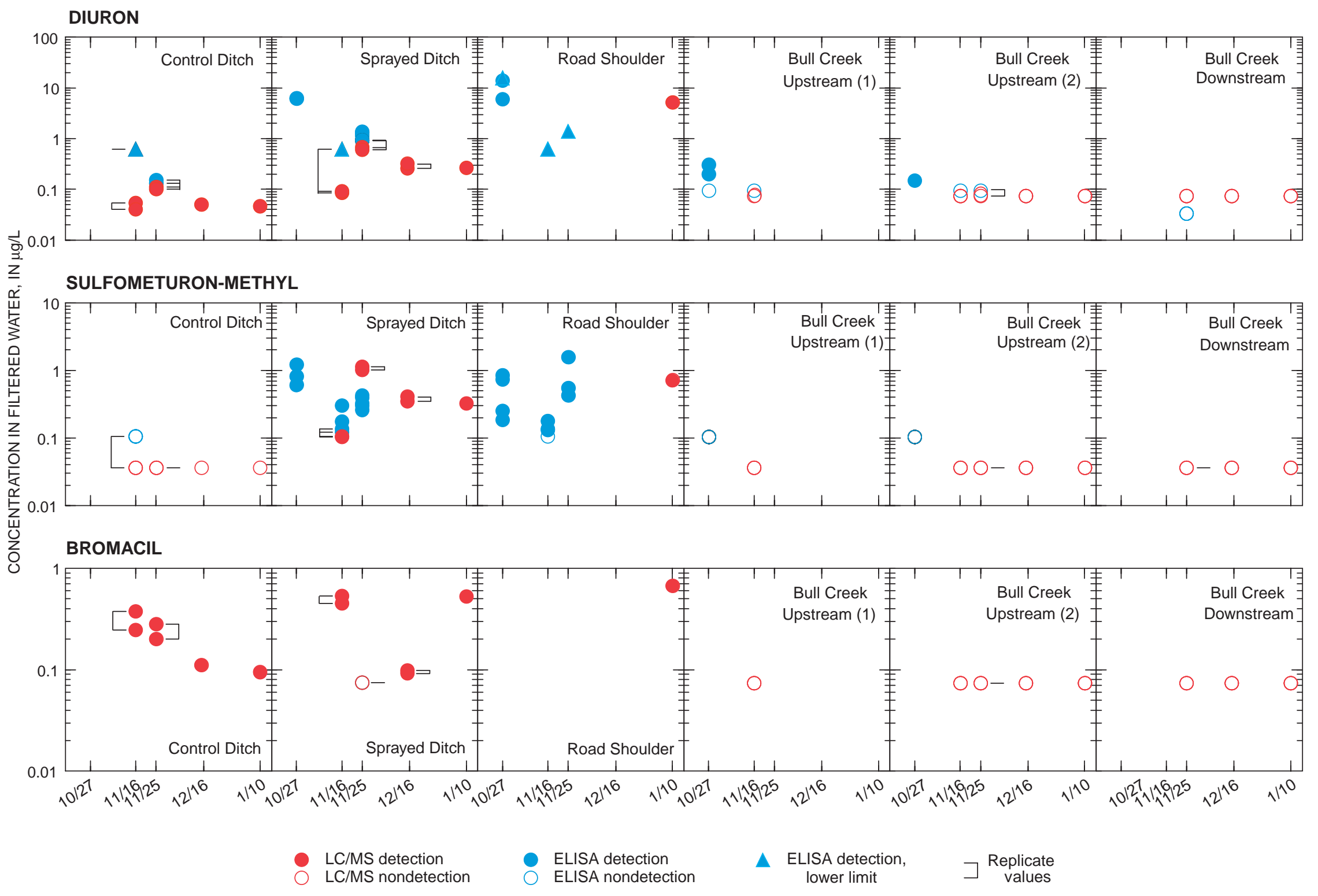

Figure 6. Diuron, sulfometuron-methyl, and bromacil concentrations in drainage ditches, runoff from the road shoulder, and Bull Creek measured during five rain events from October 1999 to January 2000. Nonreplicate ELISA values on the same sample date represent samples collected on the same date over several hours. Nondetections are shown at the method detection limit. 
Detections of triclopyr, the active ingredient in Garlon, in the control ditch provided additional evidence of a source for herbicides in the surrounding landscape. The LCMS analysis included other compounds, among them triclopyr. On two dates during the fall sample period triclopyr was detected in the water from the control ditch but not in the relatively undiluted road runoff in the sprayed ditch. The concentrations of triclopyr were comparable to those of bromacil: 0.23 and $0.17 \mu \mathrm{g} / \mathrm{L}$ on November 16 , and 0.28 and $0.15 \mu \mathrm{g} / \mathrm{L}$ on November 25 (replicate samples on both dates). Garlon was last applied by ODOT to the road shoulders along both the sprayed and control ditch in the summer of 1998; because it was not detected in the sprayed ditch it seems unlikely that its presence in the control ditch could be explained as a residual from this last application.

Glyphosate was not detected in any of the samples. Its application rate was about $60 \%$ higher than diuron, and the results of the simulated rainfall experiments indicated that it is mobilized at approximately the same percentage of the amount applied as diuron. Even if the persistence of glyphosate in the environment was comparable to that of diuron, it is unlikely that concentrations in the sprayed ditch would have been high enough on the four sample dates that samples were collected for glyphosate analysis to exceed the relatively high detection limit $(5 \mu \mathrm{g} / \mathrm{L}$, as compared to $0.07 \mu \mathrm{g} / \mathrm{L}$ for diuron and bromacil) of the LCFD method. Glyphosate concentration in the runoff from the road shoulder, however, potentially could have been above the detection limit on one of those sample dates. The fact that it was not is an indication that either glyphosate's persistence in the environment is less than that of diuron or bromacil, or that it binds so tightly to soil that it becomes immobilized over a time period of a month or more after application.

\section{DISCUSSION}

In an attempt to merge the results from the simulated rainfall experiments with the information gathered during natural rainfall, a simple loading calculation was made to mimic a worst-case situation in which a heavy rainstorm occurred 1 day, 1 week, and 2 weeks after compound application. In this calculation, it was assumed that the concentrations in the direct runoff from the road shoulder were as measured during the simulated rainfall experiment, and that the sprayed ditch carried water from the road shoulder essentially undiluted. Discharges were assumed to be as measured on the various fall sampling dates (table 13). The resulting stream concentrations in the scenario in which a rainfall of $0.3 \mathrm{in} / \mathrm{hr}$ occurred only 1 day after compound application would be $0.9-1.5 \mu \mathrm{g} / \mathrm{L}$ of diuron, $0.3-$ $0.6 \mu \mathrm{g} / \mathrm{L}$ of sulfometuron-methyl, and $0.8-1.8 \mu \mathrm{g} / \mathrm{L}$ of glyphosate. Bromacil was not measured during the simulated rainfall experiments, but because it was applied at the same rate as diuron, it could be assumed that the concentrations would be similar so soon after application. It appears, therefore, that in this small stream, ODOT operations could conceivably result in herbicide concentrations in the stream on the order of $1 \mu \mathrm{g} / \mathrm{L}$.

Stream concentrations of this magnitude probably represent a worst-case scenario, for two reasons. First, a heavy rainfall $(0.3 \mathrm{in} / \mathrm{hr})$ would be required quite soon after the application of the compounds, a situation that ODOT personnel in the Willamette Valley generally try to avoid. (The situation is somewhat different in the arid, eastern part of Oregon. A small amount of moisture is desirable to activate Krovar and Oust, and where rainfall is not plentiful, ODOT personnel might plan to take advantage of a forecasted rain, but usually not within 6 hours.) Secondly, an intensity of $0.3 \mathrm{in} / \mathrm{hr}$ was measured for only one 15-minute interval at the Camp Adams rain gage during the fall sampling period, but a rainfall between 0.1 and $0.2 \mathrm{in} / \mathrm{hr}$ was common during that period (fig. 5). Data from this study cannot be used to quantify infiltration and compound removal at those intensities; nonetheless, herbicide losses due to infiltration would clearly be greater at lower rainfall intensity.

For comparison, diuron concentrations in a previous study of herbicides in small Willamette Valley streams (Anderson et al., 1997) had a median value of $0.26 \mu \mathrm{g} / \mathrm{L}$, a 90th percentile value of $4.2 \mu \mathrm{g} / \mathrm{L}$, and a maximum of $29 \mu \mathrm{g} / \mathrm{L}$, based on 94 samples and 69 detections. Bromacil, a compound that was identified as potentially contributed by roadside and rights- of-way applications, had a median value of less than $0.035 \mu \mathrm{g} / \mathrm{L}$ (the method detection limit), a 90th percentile of $0.31 \mu \mathrm{g} / \mathrm{L}$, and a maximum value of $51 \mu \mathrm{g} / \mathrm{L}$, based on 94 samples and 14 detections. Sulfometuron-methyl and glyphosate were not included in the study of Anderson et al. (1997). Based on the results of the current study, ODOT operations could, conceivably, contribute a load resulting in concentrations close to the 90th percentile of these 
Table 13. Theoretical concentrations of herbicides in Bull Creek resulting from a hard rainfall $(0.3 \mathrm{in} / \mathrm{hr})$ between the first day and 2 weeks after compound application to the road shoulder, with discharges in the creek and drainage ditch as measured November 1999 to January 2000

[in/hr, inches per hour; $\mu \mathrm{g} / \mathrm{L}$, micrograms per liter ]

\begin{tabular}{cccc}
\hline & \multicolumn{2}{c}{$\begin{array}{c}\text { Theoretical Bull Creek concentration } \\
\text { in } \mu \mathbf{g} / \mathbf{L}, \mathbf{0}-2 \text { weeks after application: }\end{array}$} \\
\cline { 2 - 4 } $\begin{array}{c}\text { Discharge } \\
\text { as on: }\end{array}$ & $\mathbf{0}$ weeks & 1 week & 2 weeks \\
\hline \multicolumn{4}{c}{ Diuron } \\
\hline $11 / 16 / 99$ & $0.9-1.5$ & $0.3-0.6$ & $0.06-0.07$ \\
$11 / 25 / 99$ & $0.7-1.2$ & $0.3-0.5$ & $0.05-0.06$ \\
$12 / 16 / 99$ & $0.4-0.7$ & $0.2-0.3$ & 0.03 \\
$1 / 10 / 00$ & $0.4-0.7$ & $0.2-0.3$ & 0.03 \\
& Sulfometuron-methyl & \\
$11 / 16 / 99$ & $0.3-0.6$ & $0.09-0.1$ & $0.02-0.04$ \\
$11 / 25 / 99$ & $0.2-0.5$ & $0.08-0.1$ & $0.02-0.03$ \\
$12 / 16 / 99$ & $0.1-0.3$ & $0.03-0.06$ & $0.01-0.02$ \\
$1 / 10 / 00$ & $0.1-0.3$ & $0.03-0.06$ & $0.01-0.02$ \\
& Glyphosate & $0.02-0.05$ \\
$11 / 16 / 99$ & $0.8-1.8$ & $0.1-0.3$ & $0.04-0.1$ \\
$11 / 25 / 99$ & $0.6-1.5$ & $0.09-0.2$ & $0.03-0.08$ \\
$12 / 16 / 99$ & $0.4-0.8$ & $0.05-0.1$ & $0.02-0.05$ \\
\hline $1 / 10 / 00$ & $0.4-0.8$ & $0.05-0.1$ & 0.02 \\
\hline
\end{tabular}

compounds, but only if a heavy rain fell about a day after compound application, which is a rare occurrence. Rainfall within a week of compound application could still result in concentrations near the median value of diuron; by the second week after application, however, the resulting diuron concentrations would be well below the median. Based on the results of this study it seems unlikely that ODOT operations alone could have been responsible for the highest concentrations observed by Anderson et al. (1997).

With regard to the persistence of these compounds in the environment, it is probably noteworthy that after more than 3 months and 20 inches of rain at this site, diuron and bromacil, the active ingredients in Krovar, were still found in the sprayed drainage ditch at measurable, although low, concentrations (less than $1 \mu \mathrm{g} / \mathrm{L})$. This would indicate that, while the initial decrease in the availability of the compound for transport and its concentration in the runoff from the road shoulder is rapid, within a month after application that decrease is much slower. Thus, there appears to be a long-term residual of these compounds for many months after their application to the road shoulder. Most of ODOT's herbicide applications take place in the spring, which minimizes the potential for transport during the dry summer months after application, but the long-term residual transport during the fall rainy season would probably still occur. Because the total area that ODOT sprays is a small fraction of any given drainage basin, however, the concentrations in all but the most undiluted roadside drainage ditches would likely be unmeasurable at current method reporting limits.

It is also important to recognize that the results presented here are representative of a rural setting with relatively little impervious area, well-drained soils, and an unpaved drainage system to deliver runoff from the road and shoulder to a receiving stream. In a more urban environment, characterized by more impervious area and by a paved or concrete-lined drainage system, the impact of a similar-sized drainage area could be much greater.

\section{REFERENCES CITED}

Afyuni, M.M., Wagger, M.G., and Leidy, R.B., 1997, Runoff of two sulfonyl urea herbicides in relation to tillage system and rainfall intensity: Journal of Environmental Quality, v. 26, no. 5, p. 1318.

Ahuja, L.R., 1986, Characterization and modeling of chemical transfer to runoff: Springer-Verlag, New York, Advances in Soil Science, v. 4, p. 149-188.

Ahuja, L.R., Sharpley, A.N., Menzel, R.G., and Smith, S.J., 1982, Modeling the release of phosphorus and related adsorbed chemicals from soil to overland flow, in Singh, V.P., ed., Modeling components of the hydrologic cycle: Fort Collins, Colorado, Water Resources Publications, p. 463-484.

Anderson, C.W., Wood, T.M., and Morace, J.L., 1997, Distribution of dissolved pesticides and other water quality constituents in small streams, and their relation to land use in the Willamette River Basin, Oregon: U.S. Geological Survey Water-Resources Investigations Report 97-4268, $87 \mathrm{p}$.

Bailey, G.W., Swank, R.R., Jr., and Nicholson, H.P., 1974, Predicting pesticide runoff from agricultural land-A conceptual model: Journal of Environmental Quality, v. 3, p. 95.

Bowman, B.T., Wall, G.J., and King, D.J., 1994, Transport of herbicides and nutrients in surface runoff from corn cropland in southern Ontario: Canadian Journal of Soil Science, v. 74, no. 1, p. 59. 
Capel, P.D., and Larson, S.J., 1995, Evaluation of selected information on splitting devices for water samples: U.S. Geological Survey Water-Resources Investigations Report 95-4141, 103 p.

Edwards, W.M., Triplett, C.G., Jr., and Kramer, R.M., 1980, A watershed study of glyphosate transport in runoff: Journal of Environmental Quality, v. 9, p. 661.

Felsot, A.S., Mitchell, J.K., and Kenimer, A.L., 1990: Assessment of management practices for reducing pesticide runoff from sloping cropland in Illinois: Journal of Environmental Quality, v. 19, p. 539-545.

Gaynor, J.D., MacTavish, D.C., and Findlay, W.I., 1995, Atrazine and metolachlor loss in surface and subsurface runoff from three tillage treatments in corn: Journal of Environmental Quality. v. 24, p. 246-256.

Gerig, A.J., 1985, Soil survey of Clackamas County area, Oregon: U.S. Department of Agriculture, Soil Conservation Service, variable pagination.

Hall, J.K., Mumma, R.O., and Watts, D.W., 1991, Leaching and runoff losses of herbicides in a tilled and untilled field: Agriculture Ecosystems and Environment, v. 37, no. 4, p. 303-314.

Klöppel, H., Haider, J., and Kördel, W., 1994, Herbicides in surface runoff-A rainfall simulation study on small plots in the field: Chemosphere, v. 28, no. 4, p. 649.

Larson, S.J., Capel, P.D., and Majewski, M.S., 1997, Pesticides in surface waters-Distribution, trends, and governing factors-Volume 3 of the series Pesticides in the hydrologic system: Chelsea, Michigan, Ann Arbor Press, $373 \mathrm{p}$.

Lennartz, B., Louchart, X., Voltz, M., and Andrieux, P., 1997, Diuron and simazine losses to runoff water in Mediterranean vineyards: Journal of Environmental Quality, v. 26, p. 1493-1502.

Leonard, R.A., 1988, Herbicides in surface waters, in Grover, R., ed., Environmental Chemistry of Herbicides: Boca Raton, Florida, CRC Press, Inc., p. 46-87

Leonard, R.A., Langdale, G.W., and Fleming, W.G., 1979, Herbicide runoff from upland Piedmont watershedsData and implications for modeling pesticide transport: Journal of Environmental Quality, v. 8, p. 223.

Oregon Department of Transportation Highway Division, 1990, Hydraulics Manual, Salem, Oregon.

Pantone, D.J., Young, R.A., Buhler,D.D., Eberlein, C.V., Koskinen, W.C., and Forcella, F., 1992, Water quality impacts associated with pre- and postemergence applications of atrazine in maize: Journal of Environmental Quality, v. 21, p. 567-573.

Pionke, H.B., and Chesters, G., 1973, Pesticide-sedimentwater interactions: Journal of Environmental Quality. v. 2 , p. 29.

Powell, S., Neal, R., and Leyva, J., 1996, Runoff and leaching of simazine and diuron used on highway rights-of-way: State of California Environmental
Protection Agency, Department of Pesticide Regulation Report EH 96-03, variable pagination.

Rinella, F.A., and Janet, M.L., 1998, Seasonal and spatial variability of nutrients and pesticides in streams of the Willamette Basin, Oregon, 1993-95: U.S. Geological Survey Water-Resources Investigations Report 974082-C, 59 p.

Rhode, W.A., Asmussen, L.E., Hauser, E.W., and Johnson, S.W., 1979, Concentrations of ethoprop in the soil and runoff water of a small agricultural watershed: U.S. Department of Agriculture, SEA Agricultural Research Results, AFF-S-2.

Ritter, W.F., Johnson, H.P., Lovely, W.G., and Molnau, M., 1974, Atrazine, propachlor, and diazinon residues on small agricultural watersheds: Environmental Science and Technology, v. 8, no. 1, p. 38-42.

Shipitalo, M.J., Edwards, W.M., and Owens, L.B., 1997, Herbicide losses in runoff from conservation-tilled watersheds in a corn-soybean rotation: Journal of Soil Science Society of America, v. 61, no. 1, p. 267.

Smith, C.N., Leonard, R.A., Langdale, G.W., and Bailey, G.W., 1978, Transport of agricultural chemicals from small upland Piedmont watersheds: Environmental Protection Agency, EPA-600/3-78-056.

Wauchope, R.D., 1978, The pesticide content of surface water draining from agricultural fields-A review: Journal of Environmental Quality, v. 7, 459-472.

Wauchope, R.D., Buttler, T.M., Hornsby, A.G., Augustijn-Beckers, P.W.M., and Burt, J.P., 1992, The SCS/ARS/CES pesticide properties database for environmental decision-making, in Ware, G.W., ed., Reviews of environmental contamination and toxicology, Volume 123: New York, Springer-Verlag, p. 1-25.

Wauchope, R.D., and Leonard, R.A., 1980, Maximum pesticide concentrations in agricultural runoff-A semiempirical prediction formula: Journal of Environmental Quality, v. 9, no. 4, p. 665-672.

Wauchope, R.D., Williams, R.G., and Marti, L.R., 1990, Runoff of sulfometuron-methyl and cyanazine from small plots-Effects of formulation and grass cover: Journal of Environmental Quality, v. 19, p. 119-125.

White, A.W., Asmussen, L.E., Hauser, E.W., and Turnbull, J.W., 1976, Loss of 2,4-D in runoff from plots receiving simulated rainfall and from a small agricultural watershed: Journal of Environmental Quality, v. 5, p. 487.

Winfield, T.W., Bashe, W.J., and Baker, T.V., 1990, Method 547-Determination of glyphosate in drinking water by direct-aqueous-injection HPLC, post-column derivatization, and fluorescence detection, in Methods for the determination of organic compounds in drinking water-Supplement I: U.S. Environmental Protection Agency, Office of Research and Development, EPA/600/4-90/020. 
APPENDIXES 
Page Intentionally Blank 


\section{APPENDIX A: Summary of the Liquid Chromatography Mass Spectroscopy (LCMS) M ethod for Determining Diuron, B romacil, and Sulfometuron-M ethyl Concentration}

This method is designed for the determination of 65 pesticides and pesticide degradation products and caffeine in filtered natural-water samples. The method is applicable to pesticides that are (1) efficiently partitioned from the water onto a graphitized carbon-based solid-phase extraction (SPE) material, (2) can be quantitatively eluted from the SPE material, and (3) can be efficiently ionized by High Performance Liquid Chromatography/Electrospray Ionization-Mass Spectroscopy (HPLC/ESI-MS).

Pesticides are extracted from prefiltered water samples using disposable polypropylene syringe cartridges containing $0.5 \mathrm{~g}$ of a graphitized carbon sorbent. One liter of prefiltered water sample is pumped through the SPE cartridge at a flow rate of $25 \mathrm{~mL} / \mathrm{min}$. After extraction, the adsorbed compounds are eluted from the SPE cartridge using two sequential elutions of (1) $1.5 \mathrm{~mL}$ methanol followed by (2) $13 \mathrm{~mL}$ of an $80 \%$ methylene chloride and
$20 \%$ methanol mixture that has been acidified with trifluoroacetic acid $(0.2 \%)$.

The two fractions are reduced under nitrogen to near dryness and then combined. The final volume for the extract is $1,000 \mu \mathrm{L}$. Analytes are chromatographically separated by HPLC using a reverse-phase octadecylsilane HPLC column, which is coupled to an electrospray ionization interface and quadrupole mass spectrometer for detection, identification, and quantitation. Each extract is analyzed twice, once for those compounds that preferentially form positive ions under electrospray conditions, and once for those compounds that preferentially form negative ions.

The terms extraction and elution are used to define specific actions during sample processing. Extraction is the transfer of the selected compounds from the sample onto the SPE cartridge. Elution is the removal of the selected compounds from the SPE cartridge.

\section{APPENDIX B: Summary of the Method for Determining Deposition of Diuron, B romacil, Sulfometuron- Methyl, and Glyphosate on Absorbent Deposition Sheets by the Oregon Department of Agriculture}

The absorbent deposition sheets are known as "Kimbies". The sheets used in this study are manufactured by Kimberly-Clark Corporation under the trademark Kaydry.

Sulfometuron-methyl. The Kimby sheet was soaked overnight in $500 \mathrm{~mL}$ of a buffer solution $(50 \mathrm{mM}$ potassium dihydrogen phosphate, $\mathrm{pH} 6.2,20 \%$ by volume acetonitrile) with continuous agitation. Five $\mathrm{mL}$ of supernatant was removed and filtered through a $0.45 \mu \mathrm{m}$ filter. Twenty-five $\mu \mathrm{L}$ of filtrate was injected onto HPLC using $0.1 \%$ acetic acid $/ 49.9 \%$ water $/ 50 \%$ acetonitrile as the mobile phase and a C18 analytical column. Sulfometuron-methyl was detected using a photo-diode array detector monitoring $240 \mathrm{~nm}$.
Diuron and Bromacil. The Kimby sheet was soaked overnight in $500 \mathrm{~mL}$ of a buffer solution $(50 \%$ by volume water, $50 \%$ by volume methanol) with continuous agitation. Five $\mathrm{mL}$ of supernatant was removed and filtered through a $0.45 \mu \mathrm{m}$ filter. Twenty-five $\mu \mathrm{L}$ of filtrate was injected onto HPLC using 50\% acetonitrile/49\% water/ $1 \%$ acetic acid as the mobile phase and a C18 analytical column. Bromacil was monitored at $280 \mathrm{~nm}$. Diuron was monitored at $254 \mathrm{~nm}$.

Glyphosate. The Kimby sheet was soaked overnight in $500 \mathrm{~mL}$ of a $0.1 \mathrm{M} \mathrm{HCl} /$ water solution with continuous agitation. One $\mathrm{mL}$ was removed and diluted to $10 \mathrm{~mL}$ with $0.1 \mathrm{M} \mathrm{HCl}$ and filtered. Analysis was performed as described in U.S. Environmental Protection Agency method 547 utilizing HPLC with postcolumn derivatization and fluorescence spectrometry detection. 
Page Intentionally Blank 